\title{
Transformations in Representations of Gender During the Emergence of the Teotihuacan State: A Regional Case Study of Ceramic Figurines from the Basin of Mexico
}

\author{
Kiri Hagerman
}

\begin{abstract}
This paper investigates transformations in the construction and expression of gender ideologies in the Basin of Mexico from the late Middle Formative through Classic periods (approx. 800 BC-AD 600). Ceramic figurines from the sites of Teotihuacan, Axotlan, Cerro Portezuelo and Huixtoco are used to explore how elements of gender were constructed and communicated in the region over the course of a millennium, and how these practices underwent a transformation during the emergence and expansion of the Teotihuacan state. During the Formative periods, the selection, combination, or omission of sexual attributes in association with decorative elements such as jewellery formed a flexible strategy for depicting a variety of social identities across the Basin of Mexico. The emergence of the Teotihuacan figurine style in the Terminal Formative period brought with it significant changes to the way figurine bodies were formed - sexual attributes disappeared and were replaced with increasingly elaborate clothing and jewellery as the figurine corpus diversified into multiple types. Although relative rates of depictions of feminine and masculine figurines shifted over time, in no period were figurines limited to a binary set of depictions, indicating diverse social identities and gender ideologies in the Basin of Mexico over time.
\end{abstract}

Ancient figurines offer a method for investigating less tangible elements of human cultures such as gender and ideological systems and can illuminate slowmoving transformations in these systems over extended periods of time. Anthropomorphic figurines from the Basin of Mexico from the late Middle Formative through Classic periods (approx. 800 BC-AD 600) are the most numerous depictions of the human form. As such, they have a unique ability to provide us with a glimpse into how people perceived and constructed the social world around them, particularly during the emergence of Teotihuacan, the first state-level society in the region.

This paper considers figurine bodies as assemblages and examines the ways in which they were constructed, formed and decorated, and how they related to and formed larger figurine assemblages on the community and regional levels. Bodies are recognized as a locus of identity formation in the an- thropological literature, an important component of which is a person's gender. Recent work on prehistoric gender systems (Robb \& Harris 2018) has complicated the ways that archaeologists should approach the study of gender, particularly in prehistoric societies. Rather than assuming a continuous scheme of gender conceptualization rooted in the same narrow range of markers in the physical body, I consider what components were included in the shaping and ornamenting of figurine bodies over time, drawing on the anthropological literature on both gender and assemblage theory.

Visual imagery is a locale for the creation and recreation of cultural beliefs, and the act of representation is inherently linked to the discursive process of gender construction. Ancient gender ideologies, therefore, are subject to inquiries through images such as figurines that were part of the active construction of gender ideological systems. This 
article analyses four figurine assemblages from the Basin of Mexico with the goal of examining how the construction and representation of gender shifted over time. The analysis focuses on how physical and decorative elements were selected and employed to varying effect and preserved or abandoned over time. A diachronic, multi-site comparison into the strategies used to convey gender through figurines reveals how social identities were shaped, communicated and valued in Basin of Mexico society over the course of a millennium, and how gender ideologies responded to the emergence of a regional hierarchical polity.

Although much research has been conducted on the Teotihuacan state from the perspective of the core, the regional effects of Teotihuacan's rise are less well understood, particularly the ways in which rural communities interacted on social, religious and ideological levels with Teotihuacan. The figurines cannot be 'read' as accurate records of past social realities, but they do reflect salient elements of ideological systems and were active constituents in the formulation and performance of the beliefs, values and ideas therein. Identifying these values has important implications for our understanding of Teotihuacan social and ritual life, and in what ways the emergence of the Teotihuacan state affected gender ideologies in its regional orbit.

\section{Gender and the transition to state-level societies}

As a constitutive part of a person's identity, gender is a fundamental element of human social interaction and sets foundations, rules and boundaries for social life. Historically, gender has been viewed as a socially constructed feature of identity that frequently (if imperfectly) maps directly onto biological categories, and late twentieth-century anthropologists investigated the nature of the sexual division of labour and state formation. The emergence of state-level societies was thought to have had a detrimental impact on women's status (e.g. Gailey 1985; MacKinnon 1982; Sacks 1976), but the universalizing view of the causal relationship between the rise of hierarchical societies and women's loss of social power was contested even by scholars within the second-wave movement (Silverblatt 1988).

More recently, feminist and queer archaeology has complicated simple and dichotomous conceptualizations of gender, and on-going work has questioned the androcentric, Western-centric and heteronormative narratives of disciplinary tradition. Current investigations of ancient gender systems in hierarchical societies focus on individual experience, agency and subjectivity (Spencer-Wood 2011) —although the nature of the ancient individual is subject to debate (Insoll 2007; Knapp \& van Dommelen 2008)—and recognize the diverse ways in which gender intersects with other social dimensions such as age, class, race and sexuality (Brumfiel 2007; Moral 2016; Schmidt \& Voss 2000; Voss 2008). The result has been an increased scholarly awareness of the diversity of experiences within and between genders, and the particulars of gender formation, expression, relationships (Meskell 1998) and structures of power in unique historical contexts (Geller 2009a,b; Meskell 2002; Nelson 2004; 2006; 2007; Sweely 1999; Wylie 2007). The impact of socio-political transformations on gender ideologies remains an important area of archaeological research, but we must examine each society with a sensitivity to unique configurations of gender that were variable across time and space.

A person's gender identity is the result of a lifelong discursive process of creation and performance through specific actions, gestures and alterations of the body (Butler 1993; 1999). Human societies have diverse, variously configured gender systems (e.g. Hollimon 2000; Roscoe 1998), and incorporating gender into archaeological studies is not merely a matter of methodological visibility, but involves a review of our assumptions regarding the relative visibility of different genders in the archaeological record and the appropriate data necessary for studying such categories, which has also been subject to change across human history (Conkey \& Gero 1991; Robb \& Harris 2018).

Recent work by Robb and Harris (2018) further complicates archaeological investigations of gender by convincingly arguing that European Neolithic gender was radically different from later systems. They propose that gender throughout human history has shifted from contextually specific to generally observed cross-contextual systems as societies became increasingly complex and hierarchical. The implications of these findings are that gender in prehistoric societies may have been strikingly different than in later periods, but also that the same evidence we use to study gender in later societies may not be appropriate to investigating earlier systems.

\section{Assemblages of representations: making and studying gender through images}

Ancient visual imagery is an important source of evidence on how past societies communicated their beliefs about their social world (Brumfiel 1996; 2007; Gero \& Scattolin 2002, 163). As Gell (1998) cogently argued in his action-centred approach to an anthropology of art, art objects exist as part of a system of actions and reactions, and can act as agents themselves, 
thereby altering the behaviour of other agents. This provides an alternate way of conceptualizing the role of figurative art in social practice and expands the interpretive possibilities beyond purely symbolic, aesthetic, or functional approaches.

Embodiment is a popular framework for the interpretation of ancient figurative art (Joyce 2003; 2005), and is complementary to Gell's formulation of art objects as potential agents. The human body is an important site of identity formation, and modifications made to the body are akin to donning a 'social skin' that serve both generative and identifying functions (Fisher \& Loren 2003, 225). Bodily features, both natural and artificial (e.g., dress, ornamentation, jewellery, etc.), are markers of social identity and constitutive parts of the process of socialization and the embodiment of social identity (Conkey \& Hastorf 1990; Hegmon 1992; Hodder 1990; Joyce 2000; Lee 2000; 2015). Visual imagery, including figurines, is material performance of ideas about social identity, and the use, exchange, and ultimate disposal of such imagery is part of the active negotiation of social and gendered identities (Bachand et al. 2003; Joyce 2004).

These ideas have informed countless studies of gender in archaeological contexts; however, an important omission from this body of work is a clear and cogent way of making sense of diversity and change within the materials we use to study topics such as gender. The problem is compounded in studies that consider such topics over long lengths of time, or across distances of variable size. Assemblage theory, however, has emerged in recent years as a viable theoretical option to considering change and difference in regional and longitudinal assemblages.

Assemblages are a familiar concept to archaeologists, typically understood to mean aggregations of things based on either their apparent material or stylistic similarities or their association in space and time (Hamilakis \& Jones 2017, 77). Yet the perceived similarity in objects that 'belong' to an assemblage, particularly in the typological sense, can have the effect of masking, or at least devaluing, important difference within those materials. By relying on typologies as part of our descriptive and analytical process, we necessarily privilege sameness over difference, which can hinder our understanding of the diversity of artefacts and how they relate to objects outside the typological assemblage (Crellin 2017; Jones 2017). An analysis of visual imagery in particular benefits from an approach that does not focus on similarities alone.

Assemblage theory is an attempt to problematize our understanding of what an assemblage is and what it can tell us. It stems from the philosophies of
Gilles Deleuze and Felix Guattari, revisited by Manuel DeLanda (2006) and others (e.g. Crellin 2017; Hamilakis 2017; Hamilakis \& Jones 2017; Jones 2017). For example, building on Deleuze and Guattari's (1987) work on the concepts of repetition and differentiation, that of Jones (2017) complicates the concepts of style and type in archaeological investigations. In his study of British Neolithic art motifs on small decorated objects, Jones (2017) finds that such motifs referenced motifs on other materials across regions, connecting local communities through shared regional practices. Inter- and intra-referential motifs created a multi-scalar assemblage within British Neolithic art, which would not have been noticed if the analysis was constricted by artefact types. Similarly, particular objects in British Bronze Age burials were continually selected and used in conjunction with each other because of their 'specific efficacy', which together created an 'affective field' in the funerary assemblages (Fowler 2017, 104). The affective fields were multiscale assemblages that included a wide range of artefacts, materials and practices together in specific historical and temporal locations.

Crellin's (2017) discussion of change in archaeological assemblages is particularly relevant to the present topic. Rather than treat cultural and material change in punctuated, step-wise fashion as many typologies implicitly do, Crellin $(2017,118)$ argues packaging, or 'black boxing', complex assemblages of artefacts into types that periodically give way to new types and assemblages masks the dynamic process of change, which is rooted in historical processes and is rarely sudden or complete. Considering how change manifested in local, gradual and incomplete ways complicates our investigation and the resulting understanding of history and culture.

The premise of assemblage theory is the capacity of objects to be perceived, valued, used and studied in different ways, which provides theoretical room to consider the myriad ways that relationships between objects were constructed and are interpreted. Such thinking has redefined the way that archaeologists can conceive of an assemblage by both expanding it and contracting it. Many objects can form an assemblage through a network of relationships, but a single object-a human body, or a representation of one, for example — can also be an assemblage (Crellin 2017,113 ). In that case, the constituent features of said object and the way they relate to other features on similar objects complicate our use of typologies and our interpretation of relationships between objects (Jones 2017). Assemblage theory allows the archaeologist to move between multiple scales of analysis, moving from the individual object as an assemblage of 
features to a regional assemblage of objects forged by the intentional relationships between objects (Crellin 2017; DeLanda 2006).

If we consider individual figurines as assemblages of features that result from a plurality of choices, but which also form larger-scale assemblages with other figurines within and between regional communities, then a diachronic analysis of variability in anthropomorphic figurines can reveal how changes gradually accumulated, and what the significance of such changes might be. In this case, the objective is not to shoehorn figurines into stylistic typologies or preconceived categories, but rather to make sense of variability and change within local and regional assemblages.

In the current project, by looking at figurine bodies in a diachronic comparative analysis, certain properties become emergent, which expands our analysis beyond the scope of typological belonging. Since representations of the human form are rarely faithful renderings of every detail, the ways that ancient artisans shaped bodies reveal salient elements of relevant ideologies. Depictions of human bodies were part of the active and on-going process of embodiment and socialization, and can inform archaeologists on cultural beliefs about the body and its articulation with various social identities (Bahrani 2001; German 2000; Graff 2014). The interaction between different natural and cultural attributes on figurine bodies reveals that elements of local gender ideologies were significantly transformed in Basin of Mexico society over the course of a millennium, concurrent with the emergence and expansion of the Teotihuacan state.

\section{The Teotihuacan state and sites under investigation}

Located in the northeastern Basin of Mexico, Teotihuacan was a multi-ethnic metropolis that ruled an eponymous expansive state from approximately 200 to $600 \mathrm{AD}$ (Figs. 1 \& 2). The city was characterized by massive civic-ceremonial monuments, centralized planning and a large urban population that lived in over 2000 multi-family apartment compounds (Cowgill 2015; Millon 1973; Nichols 2016). Archaeological investigations have explored the religious and civic monuments of the city and multiple apartment compounds, increasing our understanding of various facets of Teotihuacan society (e.g. Cabrera Castro et al. 1991; Manzanilla 1993; 1996; 2012; Sugiyama \& Cabrera Castro 2007; Sugiyama et al. 2013; White et al. 2004).

Recent studies and reviews highlight that it remains unclear how Teotihuacan administered its hinterland in the Basin of Mexico, but that the nature of

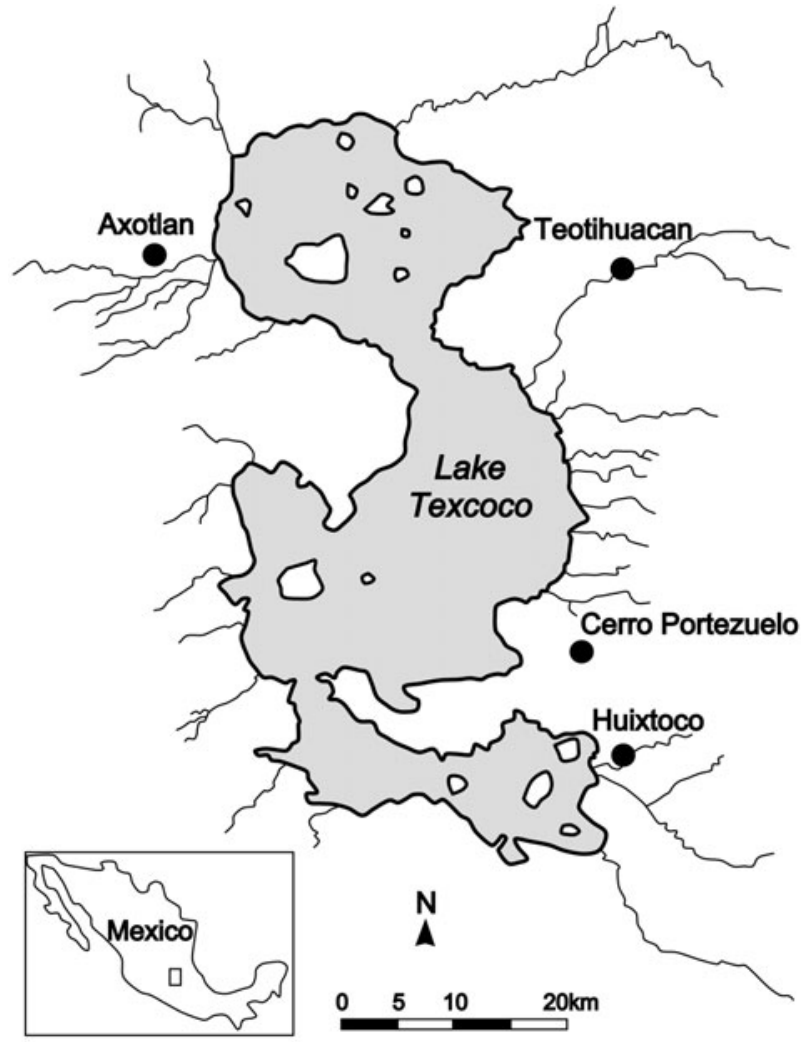

Figure 1. Basin of Mexico map showing the sites under investigation.

the socio-political relationship between the state and rural communities in the region may have been variable (Clayton 2013; Nichols 2016; Nichols et al. 2013). It remains uncertain to what extent daily life in rural communities emulated that of the city of Teotihuacan (Manzanilla 2004), and the degree of commonalities in terms of ideological and ritual practices, although Teotihuacan's borrowing of cultural elements from its neighbours is well documented (Carballo 2007; Uruñuela \& Plunket 2007).

Figurines are the single most common form of figurative art from the Basin of Mexico and represent an invaluable source of information on how social identity, and the myriad elements that constituted it, were constructed in ancient central Mexico. The figurines analysed for this study came from four different urban and rural contexts. The urban assemblage is from the city of Teotihuacan; the three rural assemblages are from the sites of Axotlan, Cerro Portezuelo and Huixtoco, which have all been covered by modern urban expansion since their excavation. The analysis of recovered materials is our only option for further investigation of these sites. 


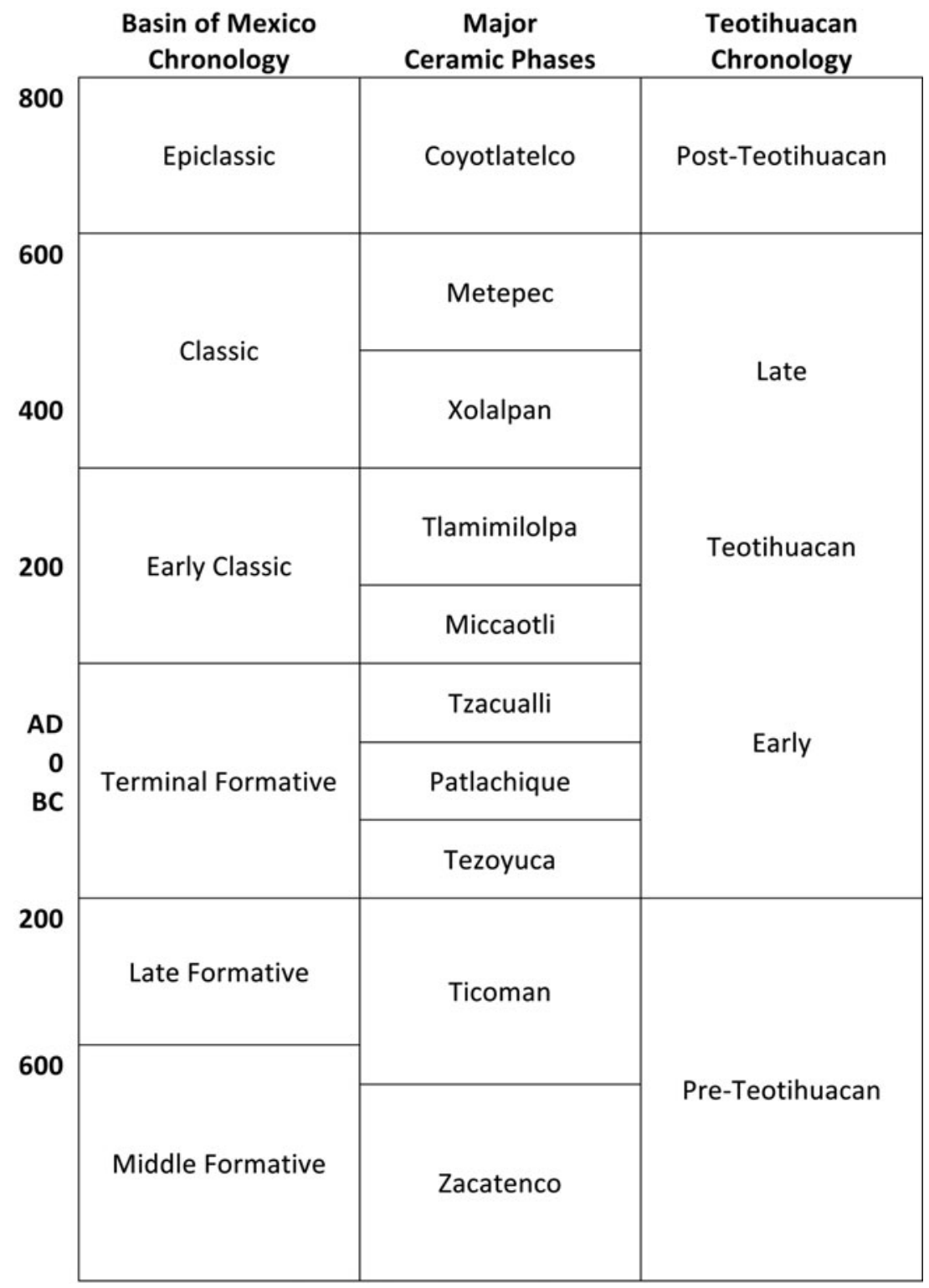

Figure 2. General chronology and ceramic phases for the Basin of Mexico.

The Teotihuacan assemblage was generated through an ambitious survey and mapping project in the 1960s and '70s, which surveyed the urban zone of Teotihuacan and produced an enormous surface collection of materials, including ceramic figurines (Millon 1973). The current study sampled 10 sq. km, approximately 25 per cent of the total area of the site, in a stratified random sample of $40500 \times 500 \mathrm{~m}$ grid squares (Fig. 3).

Axotlan is located approximately $40 \mathrm{~km}$ to the west of Teotihuacan in the Cuautitlan region (Fig. 1). Salvage excavations revealed Early Classic period architecture, artefacts and burials that strongly argued for a close relationship with Teotihuacan (Clayton
2013; García Chávez et al. 2004). The team uncovered several apartment compounds arranged in the characteristic Teotihuacan orientation of $15^{\circ}$ east of north, each containing the full range of standard Classic Teotihuacan ceramic wares and ritual artefacts such as candeleros, composite censers and ceramic figurines (García Chávez et al. 2015). The excavations did not locate any Formative period structures, leading some scholars to believe that the site was settled as part of an active rural resettlement programme by the Teotihuacan state (Clayton 2013, 90; García Chávez et al. 2015); however, Middle through Terminal Formative ceramics and figurines were found all over the site (García Chávez et al. 2004, 35, 144). The picture that 


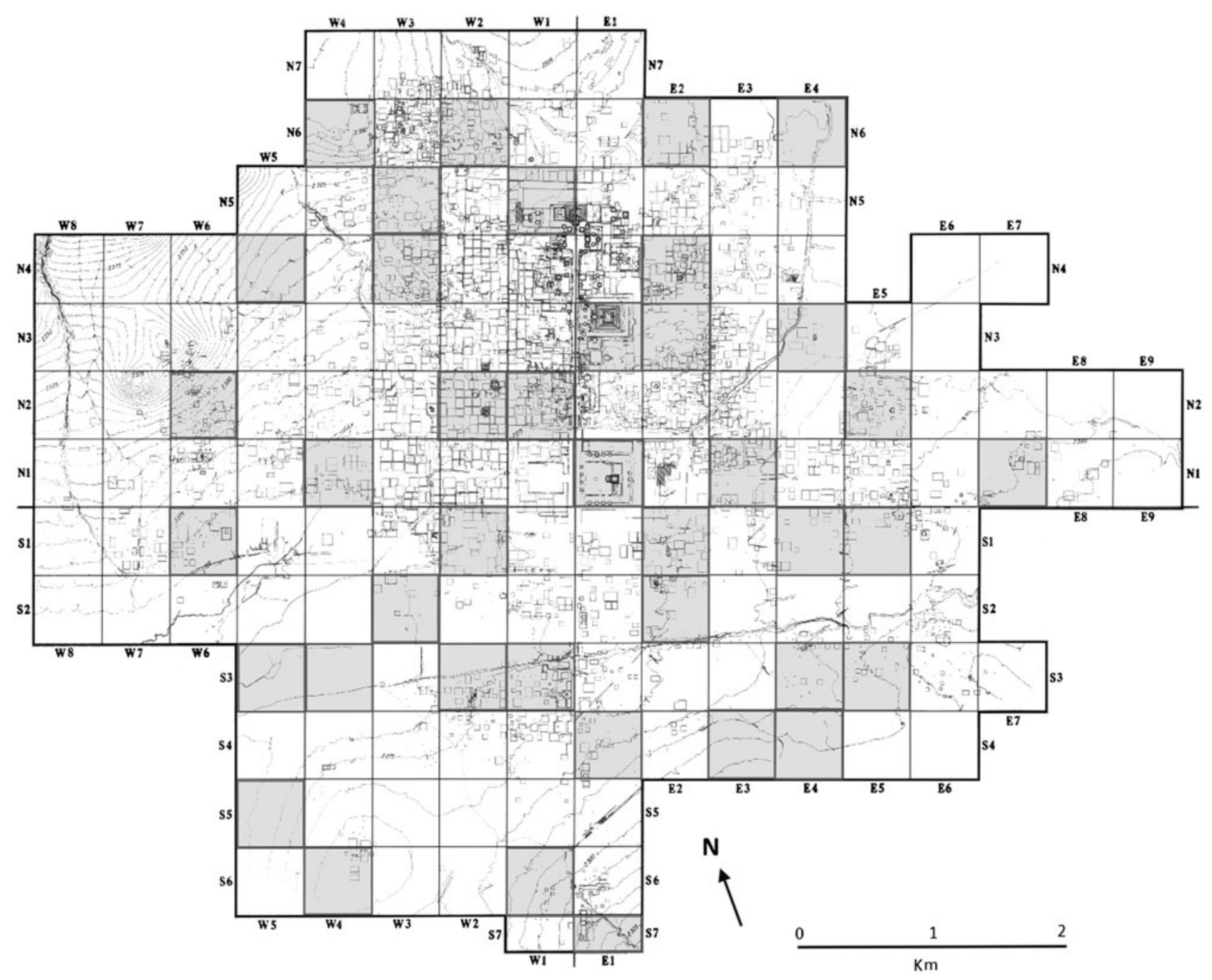

Figure 3. Teotihuacan Mapping Project site map with sampled grid squares highlighted (adapted from Millon 1973).

has emerged from research on Axotlan is of a community with strong economic and social ties to the core during the Teotihuacan period.

Cerro Portezuelo is in the Texcoco region $40 \mathrm{~km}$ south of Teotihuacan and was occupied from the Late Formative to Postclassic (Nichols et al. 2013). The site was explored in the 1950s by George Brainerd, and subsequently by Nicholson and Hicks (1961; Hicks 2013). Excavation of a Teotihuacan-period platform revealed several ceramics caches and burials (Hicks 2013), but no domestic structures were located or explored, and we do not know whether there were Teotihuacan-style apartment compounds at the site. Recent studies of recovered artefacts suggest that, although Cerro Portezuelo displayed evidence of interaction with Teotihuacan and was likely politically subordinate to it, it does not appear to have had as strong a cultural tie to Teotihuacan as did Axotlan (Clayton 2013; Nichols et al. 2013).
Huixtoco is in the Chalco region $44 \mathrm{~km}$ south of Teotihuacan. Salvage excavations revealed Formative and Teotihuacan period domestic architecture, including a Tlamimilolpa period apartment compound (Gamboa Cabezas \& García Sánchez 2015; García Chávez et al. 2015). The compound resembled the urban compounds of Teotihuacan in a variety of ways: it was oriented $15^{\circ}$ east of north, the rooms were gathered around a shared patio with evidence of an altar and the building incorporated a typical drainage system, the extension of which suggests the presence of other compounds at this site (García Chávez et al. 2015, 427). Burial patterns and practices strongly resembled those of Teotihuacan, and at least one of these burials included Thin Orange ceramics-an important Teotihuacan export. These findings indicate the presence of a Formative through Teotihuacan period occupation, and an Early Classic community at Huixtoco with strong cultural ties to the core of the state. 


\section{Gender in the Teotihuacan state}

Gender has been an important subject of research at Teotihuacan for the past half-century; however, the nature of Teotihuacan gender ideologies is still debated, particularly in the rural periphery. Some have argued that gender was not an important factor in structuring relations at Teotihuacan (e.g. De Lucia 2008), and certain evidence indeed points to a less rigid gender hierarchy than in other contemporary societies. De Lucia (2008) argues that group identity and community affiliation was a more salient structuring principle than individual identity and gender in Classic period Teotihuacan, and apartment compounds are known to have been an important space for economic, ritual and social interaction (De Lucia 2008, 30).

Sempowski (1994) has argued that women in Teotihuacan society had less social standing than men based on the observation that female skeletons on average had fewer grave goods than male skeletons; however, Clayton's $(2009$; 2011) investigations indicate that the status of men and women in Teotihuacan society was variable and dependent on social, economic and temporal contexts. In her comparison of mortuary practices in several urban apartment compounds and one compound at Axotlan, Clayton found that, even though female burials were less likely than male burials to have associated grave goods, the difference was not statistically significant. The significant difference occurred in rates of grave goods between locales, as well as several other elements of mortuary practice. A comparison of the full range of associated burial behaviours does not support the idea of a strict and uniform gender hierarchy; more striking is the internal variation in practices within Teotihuacan society.

\section{Figurines in the Basin of Mexico from the Middle Formative to Classic periods}

Ceramic figurines were a ubiquitous feature of Basin of Mexico cultures from the Middle Formative to Postclassic periods (c. $1000 \mathrm{BC}-\mathrm{AD} 1500)$, and there is a robust body of research on Mesoamerican figurines (e.g. Brumfiel 1996; Faust \& Halperin 2009; Lesure 2011; 2015; Vaillant 1930; 1931; Vaillant \& Vaillant 1934). Millions of Teotihuacan figurines were likely produced between the Terminal Formative and Classic periods (Barbour 1975), yet there is a perplexing lack of scholarly publications on Teotihuacan figurines, apart from dissertations (e.g. Barbour 1975; Goldsmith 2000; Scott 1994; Sullivan 2007; cf. Scott 2001).
Ceramic figurines in the Basin of Mexico can be hand-made or moulded. Formative figurines were exclusively hand-made, but moulds became the dominant method of production when they were developed during the Early Classic period (c. 250-350 AD). Hand-modelled bodies continued to be produced through the Classic but were combined with moulded heads and headdresses. Many figurines were originally painted, but few retain their pigment. Method of production is moderately helpful in phasing Teotihuacan period figurine fragments, but stylistic attributes are the most accepted way of dating for all periods. I draw on the Hay-Vaillant system for dating Middle and Late Formative figurines (Vaillant 1930; 1931), and on the works of Goldsmith (2000), Montoya (2001) and Scott (2001) for Teotihuacan period figurines.

Figurines were a constant presence in Formative and Teotihuacan period sites in the Basin of Mexico and their use appears to have been diverse. Formative figurines are found in domestic spaces, middens and burials, and while evidence of production is scarce, it is generally assumed that they were produced within households (Lesure 2011; Marcus 2009). Evidence from the neighbouring region of Tlaxcala indicates that Formative figurines were widely circulated within and outside the Basin (Lesure 2015), and although local stylistic features occurred, there was a remarkable level of cohesion in terms of subject matter and style between distant sites.

Production of figurines within Teotihuacan is known to have occurred in both attached and independent workshops; a workshop adjacent to the Ciudadela produced multiple types of moulded figurines among other ritually important ceramics (such as theatre censers), suggesting the involvement of elite or state officials in figurine production, but multiple sites of independent production have also been discovered in apartment compounds across the city (Barbour 1975; Cabrera Castro et al. 1991; Sugiyama 2002; Sullivan 2007), and there is compelling evidence that at least some rural sites produced figurines as well. Teotihuacan period figurines are typically found broken and in secondary contexts such as architectural fill, or in courtyards and other domestic spaces (Goldsmith 2000; Scott 2001). Although they have been found in mortuary contexts, they never appear in more than a quarter of burials at any compound (Clayton 2009; Linné 1934; Sempowski 1994; Manzanilla 1993), and caching does not appear to have been the primary use, given the paucity of this behaviour (cf. Rodriguez Sanchez \& Delgado Rubio 1997). The primary use of Teotihuacan figurines, therefore, seems to have been in quotidian or domestic ritual activities. 
Domestic ritual at Teotihuacan was centred in the shared patios of apartment compounds, which typically held altars and a range of ritually associated material objects including theatre censers, temple models, Huehueteotl statuettes, candeleros, effigy vessels and figurines (Manzanilla 2002). Certain figurine types are associated with termination and abandonment rituals and are found near apartment compound altars (Cabrera Cortés 2011, 275). Furthermore, the disappearance of many of the above artefact types after the collapse of Teotihuacan suggests that domestic ritual was strongly aligned with state religion (Cowgill 1997). The specific uses for the full range of figurine types are not well understood, but that is not a complete barrier to their use in archaeological studies, since they still reflect salient beliefs and priorities (Brumfiel 2001, 305).

The data for this study were generated by a larger diachronic study of ritual diversity and changes in figurine use in the Basin of Mexico (Hagerman 2018). Between all four sites under investigation, over 9000 figurine fragments were analysed, the majority of which were from Teotihuacan. Here, I report those figurines that could be confidently phased, concentrating on torso fragments $(n=2045)$ as they contain many features relevant to this study and provide a larger sample size to work with compared to heads, which are typically separated from the bodies and are curated at higher rates, leaving many surface collections with lower head counts. Sample sizes for some periods and sites are unfortunately quite small; however, in the aggregate a clear pattern emerges in the region as different features including sexual attributes, jewellery and clothing were adopted and rejected by figurine makers over time.

\section{The selection and depiction of sexual attributes on figurines}

Diachronic variations were observed in multiple ways in the regional figurine assemblages, but the variation and changes in the presence, selection and combination of sexual attributes were particularly noticeable. Sexual attributes on figurine torsos were most common during the Formative periods and were made using various techniques, including modelling the clay during the initial formation of the torso, subsequent appliquéing or incising, or a combination of all techniques.

Gynomorphic characteristics such as breasts, pregnant abdomens, pubic triangles and vulvae were common, especially in the earlier periods under consideration (Fig. 4); however, they were not ubiquitous. Several instances of andromorphic features $(n=5)$ were recorded at two of the sites, but were temporally restricted to the Middle and early Late Formative (Fig. 5), and torsos without any sexual attributes were found at moderate to high rates in every period.

Sexual attributes were most common on Middle and Late Formative period figurines (Table 1). During the Middle Formative, nearly half of all figurine torsos in the study had at least one sexual attribute: this was mostly due to their prevalence at Huixtoco, however, where almost two-thirds of the torsos had sexual attributes of some kind. In the same period, sexual attributes were also found on figurines at Axotlan and Cerro Portezuelo, but the sample sizes were too low to speak about relative prevalence. No Middle Formative torsos were found at Teotihuacan.

Although the common occurrence of diverse sexual attributes during the Middle Formative is striking, equally striking is the fact that over half of the figurine torsos did not have sexual attributes of any kind-andromorphic or gynomorphic. Breakage has potentially increased this number somewhat; however, enough of the torsos were sufficiently intact to give us a reasonable idea that they did not originally contain sexual attributes. Although the frequency of sexual attributes might lead many to focus on their potential significance, it is equally important to keep in mind that they were not present on the majority of figurine bodies. Such bodies were formed and shaped along similar lines, made in similar sizes and received similar surface treatments, except for the absence of sexual attributes. The absence of sexual attributes was a purposeful omission by figurine makers who formed figurines that stylistically resonated in many ways with figurines that did have such attributes. All these figurines should be seen as intentional elements of the same assemblages.

The rate of sexual attributes on figurines rose to 60 per cent in the Late Formative before declining steeply in the subsequent period. Counts were extremely low at Cerro Portezuelo and Teotihuacan; however, both sites did yield torsos with sexual attributes. Counts were higher in the Axotlan and Huixtoco assemblages and sexual attributes were prevalent.

The regional rate of sexual attributes dropped dramatically in the Terminal Formative period, when only 7 per cent of figurines in the Basin of Mexico had any evidence of such attributes. The highest rate of sexual attributes occurred at Cerro Portezuelo, where a quarter of figurines had some sort of sexual attribute, but there were six times as many examples in the much larger Teotihuacan assemblage, where the relative rate was much lower. All sexual attributes ceased by the end of the Terminal Formative at all 

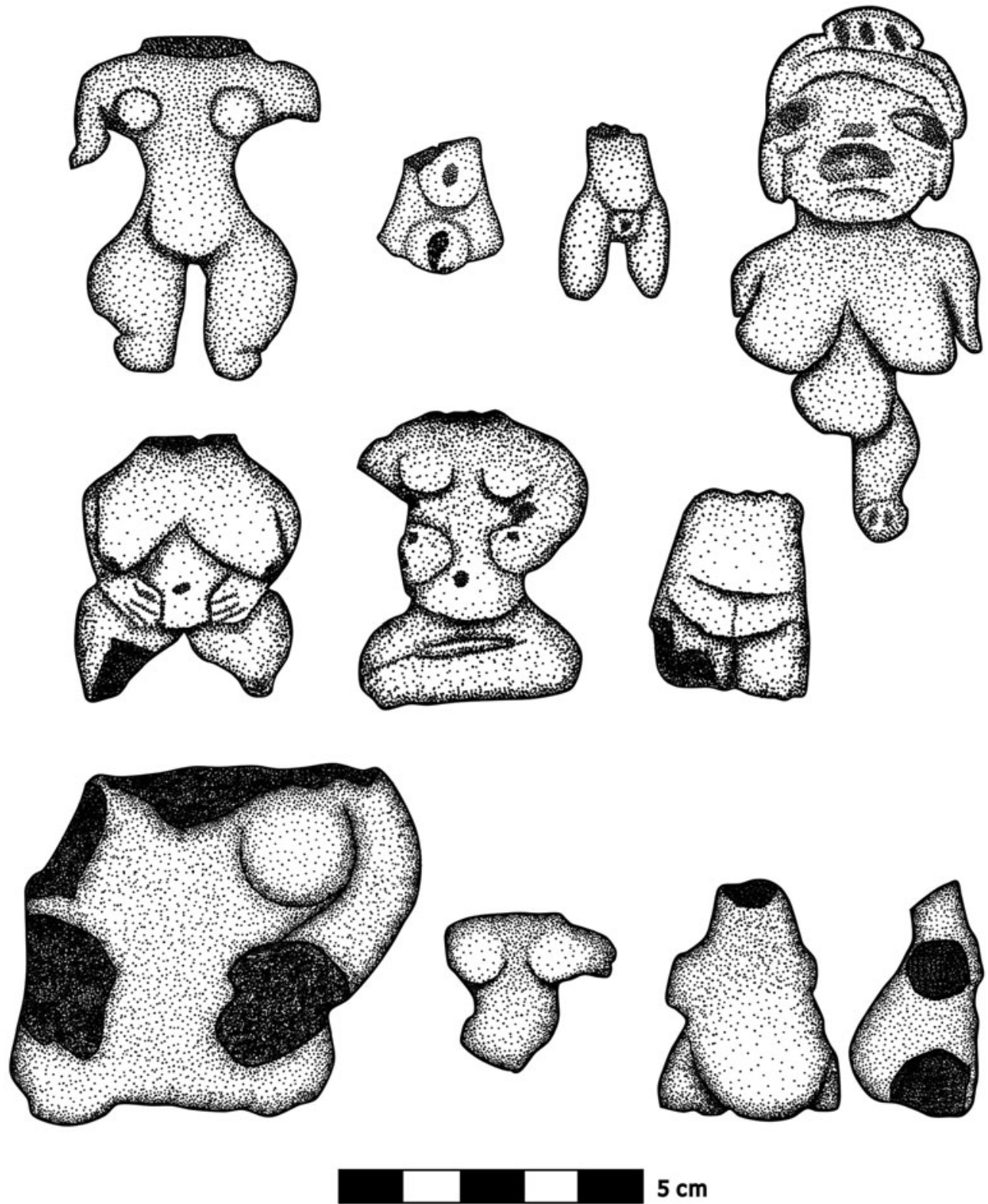

Figure 4. Middle and Late Formative gynomorphic sexual attributes from Huixtoco (top row) and Axotlan (middle row), and Terminal Formative gynomorphs from Teotihuacan (bottom row.) (Drawings: K. Hagerman.)

sites; no sexual attributes occurred after that point on nude or clothed torsos.

Measuring the presence or absence of sexual attributes only scratches the surface of what was a highly complex and variable system of representation. Diachronic variations were observed in the frequency and combination of different sexual attributes, indicating potential changes in preferences over time (Table 2). During the Middle Formative, breasts were by far the most common attribute overall, followed by a few other primary and secondary sexual characteristics. Although breasts remained the most frequently encountered attribute in the Late Formative, other gynomorphic attributes including pregnant torsos, pubic triangles and vulvae became much more common at Axotlan and Huixtoco- - the counts were extremely low at the other two sites during this periodand four examples of andromorphic attributes were found in the Huixtoco assemblage. These sexual characteristics were not evenly distributed across the sites, 


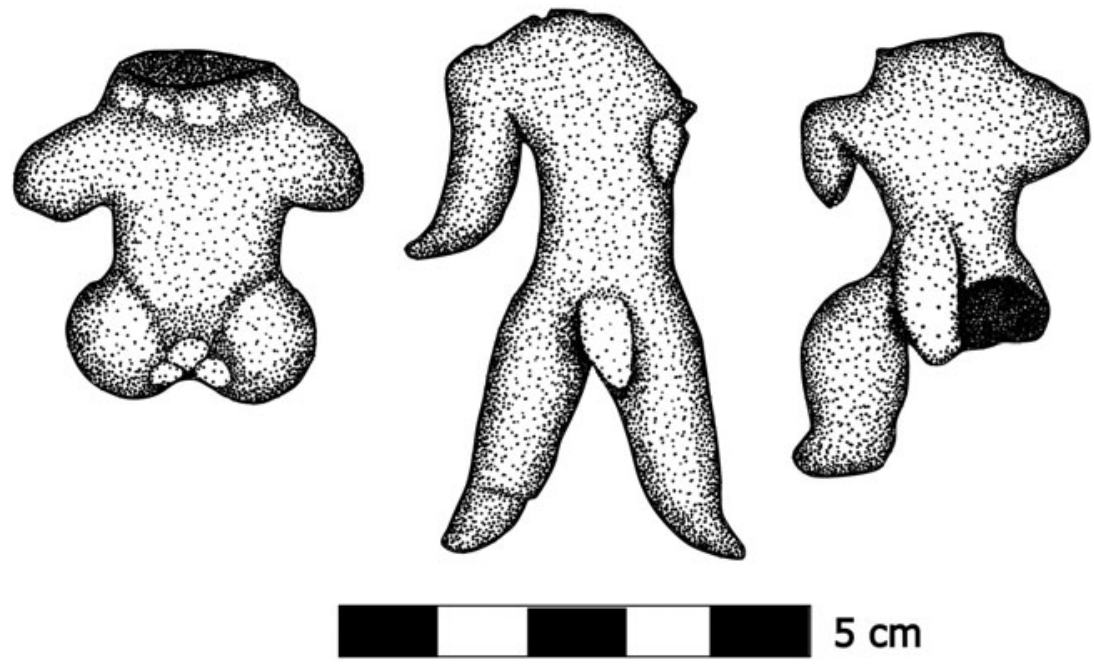

Figure 5. Middle and Late Formative andromorphic figurines from Axotlan (left) and Huixtoco (middle and right). (Drawings: K. Hagerman.)

however, which could be an effect of low counts in several of the sites but could also indicate a degree of local preferences for certain attributes at different sites.

Co-occurrence of sexual attributes was limited to the Middle through Terminal Formative periods, and was most common in the Late Formative (Table 3). Furthermore, most cases occurred in Huixtoco, where five different combinations of sexual attributes were observed, although several combinations were more prevalent, indicating that these may have been common arrangements. Even though sexual attributes were common at the other sites, co-occurrence was low at Axotlan and Cerro Portezuelo and entirely absent in the Teotihuacan assemblage.

A clear indication of preference can be seen in the Terminal Formative as both the frequency and the range of sexual attributes declined. With only one exception at Cerro Portezuelo, primary sexual characteristics disappeared. Breasts and pregnant torsos were virtually the only sexual attributes present during this period and occurred in high numbers at both Cerro Portezuelo and Teotihuacan. Interestingly, although depictions of breasts and pregnant torsos were common in the early Teotihuacan assemblage, the two attributes were never observed to co-occur-a possible confound to the interpretation of distended torsos representing pregnancy at the site.

\section{Style and ornamentation in bodily representations}

When sexual attributes and forms of bodily ornamentation such as jewellery and clothing were considered together as variable schemes of depicting elements of social identity, some interesting patterns emerged in the ways in which physical attributes and ornamentation were employed over time (Table 4). Sexual attributes as a representational strategy were quickly abandoned during the growth of Teotihuacan as a regional power in the Terminal Formative, replaced by jewellery and clothing as markers of social and gendered identities.

Sexual attributes and jewellery were both features that could be employed, combined, or omitted on figurine bodies, and there was not a consistent pattern of doing so in the Formative periods (Table 4). In the Middle Formative period, the most common representational choice was figurines with no sexual attributes or jewellery, followed by jewellery combined with sexual attributes or jewellery alone, and sexual attributes alone were the least common mode of representation. In the Late Formative, sexual attributes alone became the most popular mode of representation, followed by neither jewellery nor sexual attributes; the two conditions that included jewellery were the least common.

The preponderance of plain torsos in the Terminal Formative period contrasted sharply with earlier periods. Most figurines had no sexual attributes or jewellery and the second most common choice was jewellery alone. In the Early Classic, jewellery became increasingly common on figurines, and individual figurines wore more elaborate jewellery than in any of the Formative periods (Figs. 6 \& 7). By the Classic, only one figurine type (i.e. warriors) did not wear jewellery-all others routinely wore large amounts, including multiple collars and earspools. 
Table 1. Rates of sexual attributes on figurine torsos by period and site ( $A X T=$ Axotlan; $C P Z=$ Cerro Portezuelo; $H X T=H u i x t o c o ; T E O=$ Teotihuacan).

\begin{tabular}{|c|c|c|c|c|c|c|}
\hline Period & Site & $\begin{array}{c}\text { Sexual } \\
\text { attributes }\end{array}$ & $\begin{array}{c}\text { None/ } \\
\text { unknown }\end{array}$ & $\begin{array}{c}\text { Total } \\
\text { torsos }\end{array}$ & $\begin{array}{r}\% \mathrm{To} \\
\text { sexua }\end{array}$ & $\begin{array}{l}\text { with } \\
\text { ibutes }\end{array}$ \\
\hline \multirow{6}{*}{$\begin{array}{l}\text { Middle } \\
\text { Formative }\end{array}$} & AXT & 2 & 16 & 18 & $11 \%$ & (2) \\
\hline & $\mathrm{CPZ}$ & 1 & 1 & 2 & $50 \%$ & (1) \\
\hline & HXT & 18 & 11 & 29 & $62 \%$ & (18) \\
\hline & TEO & & & & & \\
\hline & Total & 21 & 28 & 49 & & \\
\hline & $\%$ & $43 \%$ & $57 \%$ & $100 \%$ & & \\
\hline \multirow{6}{*}{$\begin{array}{l}\text { Late } \\
\text { Formative }\end{array}$} & AXT & 12 & 9 & 21 & $57 \%$ & (12) \\
\hline & $\mathrm{CPZ}$ & 1 & 1 & 2 & $50 \%$ & (1) \\
\hline & HXT & 48 & 31 & 79 & $61 \%$ & $(48)$ \\
\hline & TEO & 2 & 1 & 3 & $67 \%$ & (2) \\
\hline & Total & 63 & 42 & 105 & & \\
\hline & $\%$ & $60 \%$ & $40 \%$ & $100 \%$ & & \\
\hline \multirow{6}{*}{$\begin{array}{l}\text { Terminal } \\
\text { Formative }\end{array}$} & AXT & 1 & 22 & 23 & $4 \%$ & (1) \\
\hline & $\mathrm{CPZ}$ & 8 & 25 & 33 & $24 \%$ & (8) \\
\hline & HXT & & & & & \\
\hline & TEO & 50 & 737 & 787 & $6 \%$ & (50) \\
\hline & Total & 59 & 784 & 843 & & \\
\hline & $\%$ & $7 \%$ & $93 \%$ & $100 \%$ & & \\
\hline \multirow{6}{*}{$\begin{array}{l}\text { Early } \\
\text { Classic }\end{array}$} & AXT & & 41 & 41 & & \\
\hline & $\mathrm{CPZ}$ & & 13 & 13 & & \\
\hline & HXT & & & & & \\
\hline & TEO & & 366 & 366 & & \\
\hline & Total & & 420 & 420 & & \\
\hline & $\%$ & & $51 \%$ & $100 \%$ & & \\
\hline \multirow{6}{*}{ Classic } & AXT & & 56 & 56 & & \\
\hline & $\mathrm{CPZ}$ & & 10 & 10 & & \\
\hline & HXT & & 3 & 3 & & \\
\hline & TEO & & 559 & 559 & & \\
\hline & Total & & 628 & 628 & & \\
\hline & $\%$ & & $100 \%$ & $100 \%$ & & \\
\hline
\end{tabular}

The presence of sexual attributes was inversely correlated with clothing over time, indicating a change in the strategy for representing bodies and a potential change in ideas about social and gendered identities (Table 5; Fig. 8). Although clothing and sexual attributes were not mutually exclusive, they were only combined in a minority of cases $(n=15)$ during the periods in question. Clothing was present in every period, although during the Middle and Late Formative periods it occurred on only 5 per cent of figurines and was most commonly a simple appliquéd belt. During the Middle Formative, clothing was limited to figurines from Huixtoco, and then appeared in small numbers at Axotlan in the Late Formative. There was no clothing found in the Cerro Portezuelo or Teotihuacan assemblages until the Terminal Formative.

During the Terminal Formative, the overall rate of clothing increased to 29 per cent, and new styles of clothing emerged. Masculine clothing such as belts and loincloths became increasingly common and elaborate (Fig. 7). The increase in masculine clothing during the Terminal Formative is interesting, since gynomorphic sexual attributes continued to be employed in the regional assemblages. And 18 examples of quechquemitls or huipils (traditional feminine garments) were found on Terminal Formative figurines, almost exclusively at Teotihuacan.

Nearly half of all figurine torsos wore clothing by the Early Classic. Masculine attire such as 


\section{Kiri Hagerman}

Table 2. Counts and rates of different sexual attributes by site and period

( AXT=Axotlan; $C P Z=$ Cerro Portezuelo; HXT $=$ Huixtoco; $T E O=$ Teotihuacan $)$

\begin{tabular}{|c|c|c|c|c|c|c|c|}
\hline Period & Site & Breasts & Pregnant & $\begin{array}{c}\text { Pubic } \\
\text { triangle }\end{array}$ & Vulva & Penis & $\begin{array}{c}\text { Total } \\
\text { attributes }\end{array}$ \\
\hline \multirow{6}{*}{$\begin{array}{l}\text { Middle } \\
\text { Formative }\end{array}$} & AXT & 1 & 1 & & & 1 & 3 \\
\hline & $\mathrm{CPZ}$ & 1 & & & & & 1 \\
\hline & HXT & 17 & & 1 & & & 18 \\
\hline & TEO & & & & & & \\
\hline & Total & 19 & 1 & 1 & & 1 & 22 \\
\hline & $\%$ & $86 \%$ & $5 \%$ & $5 \%$ & & $5 \%$ & $100 \%$ \\
\hline \multirow{6}{*}{$\begin{array}{l}\text { Late } \\
\text { Formative }\end{array}$} & AXT & 7 & 3 & 2 & & & 12 \\
\hline & $\mathrm{CPZ}$ & 1 & & & & & 1 \\
\hline & HXT & 28 & 11 & 4 & 16 & 4 & 63 \\
\hline & TEO & 2 & & & & & 2 \\
\hline & Total & 38 & 14 & 6 & 16 & 4 & 78 \\
\hline & $\%$ & $49 \%$ & $18 \%$ & $8 \%$ & $21 \%$ & $5 \%$ & $100 \%$ \\
\hline \multirow{6}{*}{$\begin{array}{l}\text { Terminal } \\
\text { Formative }\end{array}$} & AXT & & 1 & & & & 1 \\
\hline & $\mathrm{CPZ}$ & 7 & 1 & & 1 & & 9 \\
\hline & HXT & & & & & & \\
\hline & TEO & 23 & 27 & & & & 50 \\
\hline & Total & 30 & 29 & & 1 & & 60 \\
\hline & $\%$ & $50 \%$ & $48 \%$ & & $2 \%$ & & $100 \%$ \\
\hline \multirow{4}{*}{$\begin{array}{l}\text { Early } \\
\text { Classic }\end{array}$} & AXT & & & & & & \\
\hline & $\mathrm{CPZ}$ & & & & & & \\
\hline & HXT & & & & & & \\
\hline & TEO & & & & & & \\
\hline \multirow{4}{*}{ Classic } & AXT & & & & & & \\
\hline & $\mathrm{CPZ}$ & & & & & & \\
\hline & HXT & & & & & & \\
\hline & TEO & & & & & & \\
\hline
\end{tabular}

Table 3. Counts and rates of the co-occurrence of sexual attributes on figurine torsos by site and period $(A X T=A x o t l a n ; C P Z=C e r r o$ Portezuelo; HXT= Huixtoco; TEO= Teotihuacan).

\begin{tabular}{|c|c|c|c|c|c|c|c|c|c|c|}
\hline Period & Site & $\begin{array}{c}\text { Breasts } \\
\text { Vulva }\end{array}$ & $\begin{array}{c}\text { Breasts } \\
\text { Pregnant }\end{array}$ & $\begin{array}{c}\text { Breasts } \\
\text { Pregnant } \\
\text { Vulva }\end{array}$ & $\begin{array}{l}\text { Pregnant } \\
\text { Vulva }\end{array}$ & $\begin{array}{c}\text { Pregnant } \\
\text { Pubic } \\
\text { triangle }\end{array}$ & $\begin{array}{l}\text { Pubic } \\
\text { triangle } \\
\text { Breasts }\end{array}$ & $\begin{array}{c}\text { Total } \\
\text { torsos } \\
\text { with } \\
\text { sexual } \\
\text { attributes }\end{array}$ & $\begin{array}{l}\text { Total cases } \\
\text { of co- } \\
\text { occurrence }\end{array}$ & $\begin{array}{l}\text { Rate of co- } \\
\text { occurrence }\end{array}$ \\
\hline \multirow{4}{*}{$\begin{array}{l}\text { Middle } \\
\text { Formative }\end{array}$} & $\mathrm{AXT}$ & & 1 & & & & & 2 & 1 & $50 \%$ \\
\hline & $\mathrm{CPZ}$ & & & & & & & 1 & & \\
\hline & HXT & & & & & & & 18 & & \\
\hline & TEO & & & & & & & & & \\
\hline \multirow{4}{*}{$\begin{array}{l}\text { Late } \\
\text { Formative }\end{array}$} & AXT & & 2 & & & & 1 & 12 & 3 & $25 \%$ \\
\hline & $\mathrm{CPZ}$ & & & & & & & 1 & & \\
\hline & HXT & 5 & 5 & 1 & 3 & 1 & & 48 & 15 & $31 \%$ \\
\hline & TEO & & & & & & & 2 & & \\
\hline \multirow{4}{*}{$\begin{array}{l}\text { Terminal } \\
\text { Formative }\end{array}$} & AXT & & & & & & & 1 & & \\
\hline & $\mathrm{CPZ}$ & & 1 & & & & & 8 & 1 & $13 \%$ \\
\hline & HXT & & & & & & & & & \\
\hline & TEO & & & & & & & 50 & & \\
\hline
\end{tabular}



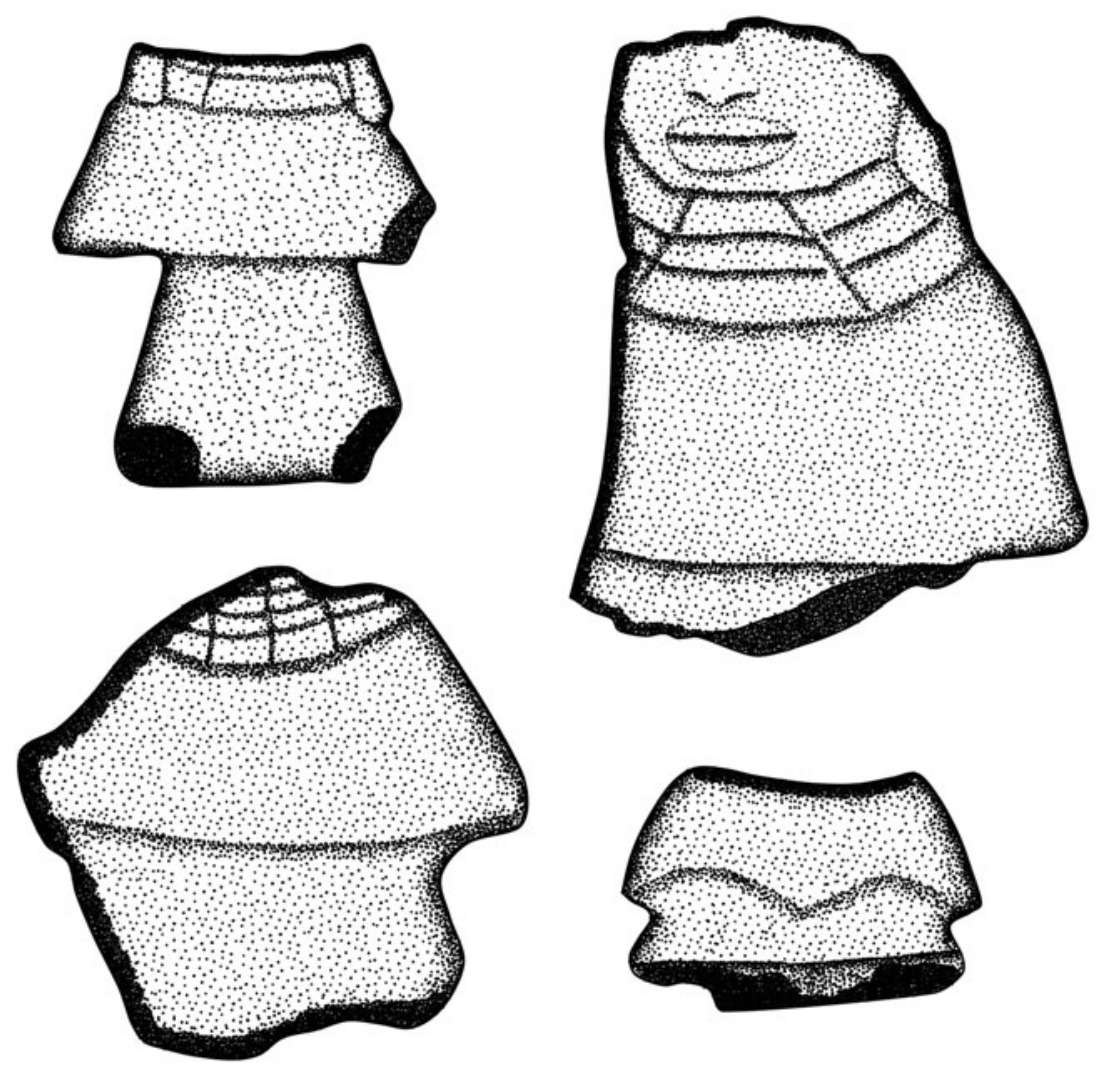

$5 \mathrm{~cm}$

Figure 6. Teotihuacan feminine figurines. Top: handmade Early Classic figurines from Teotihuacan (left) and Axotlan (right); bottom: moulded Classic figurines from Huixtoco (left) and Cerro Portezuelo (right). (Drawings: K. Hagerman.)

Table 4. Rates of sexual attributes, jewellery and combinations on figurine Ttorsos by period (all sites).

\begin{tabular}{|l|c|c|c|c|c|}
\hline Period & $\begin{array}{c}\text { Sex } \\
\text { attributes } \\
\text { only }\end{array}$ & $\begin{array}{c}\text { Jewellery } \\
\text { only }\end{array}$ & Both & Neither & Total \\
\hline $\begin{array}{l}\text { Middle } \\
\text { Formative }\end{array}$ & 9 & 12 & 12 & 16 & $\mathbf{4 9}$ \\
\hline$\%$ & $18 \%$ & $24 \%$ & $24 \%$ & $33 \%$ & $100 \%$ \\
\hline $\begin{array}{l}\text { Late } \\
\text { Formative }\end{array}$ & 48 & 9 & 15 & 33 & $\mathbf{1 0 5}$ \\
\hline$\%$ & $46 \%$ & $9 \%$ & $14 \%$ & $31 \%$ & $100 \%$ \\
\hline $\begin{array}{l}\text { Terminal } \\
\text { Formative }\end{array}$ & 49 & 165 & 10 & 619 & $\mathbf{8 4 3}$ \\
\hline$\%$ & $6 \%$ & $20 \%$ & $1 \%$ & $73 \%$ & $100 \%$ \\
\hline
\end{tabular}

belts, loincloths, tunics and capes became increasingly elaborate during the Early Classic (Fig. 7). Belts and loincloths carried extra ornamentation, and some figurines wore appliquéd clothing resembling pants. As masculine clothing diversified, representations of women across the Basin simultaneously became fully clothed and remarkably standardized, and there was very little subsequent alteration made to this class of figurine over the next 300 years. Women invariably wore a huipil (long, dress-like tunic) or skirt and quechquemitl (a shawl or poncho-like garment that covers the shoulders) - variations of which formed the traditional pre-Hispanic outfit for women-with standardized jewellery, and this became the only visual language for denoting femininity in figurines from then on (Fig. 6).

Furthermore, and in contrast to masculine figurines, in some cases the bodies of feminine figurines were quite literally their clothing. There were two ways of forming the Early Classic feminine figurine: one was to make a simple coil body and then attach thin sheets of clay to the body to form the clothing, but figurines made in the second method lacked any internal body and were simply constructed from the clay slab clothing itself.

The rate of clothing declined somewhat during the Classic, but this was due to the emergence and popularity of articulated and warrior figurines at Teotihuacan, which never wore clothing (although 

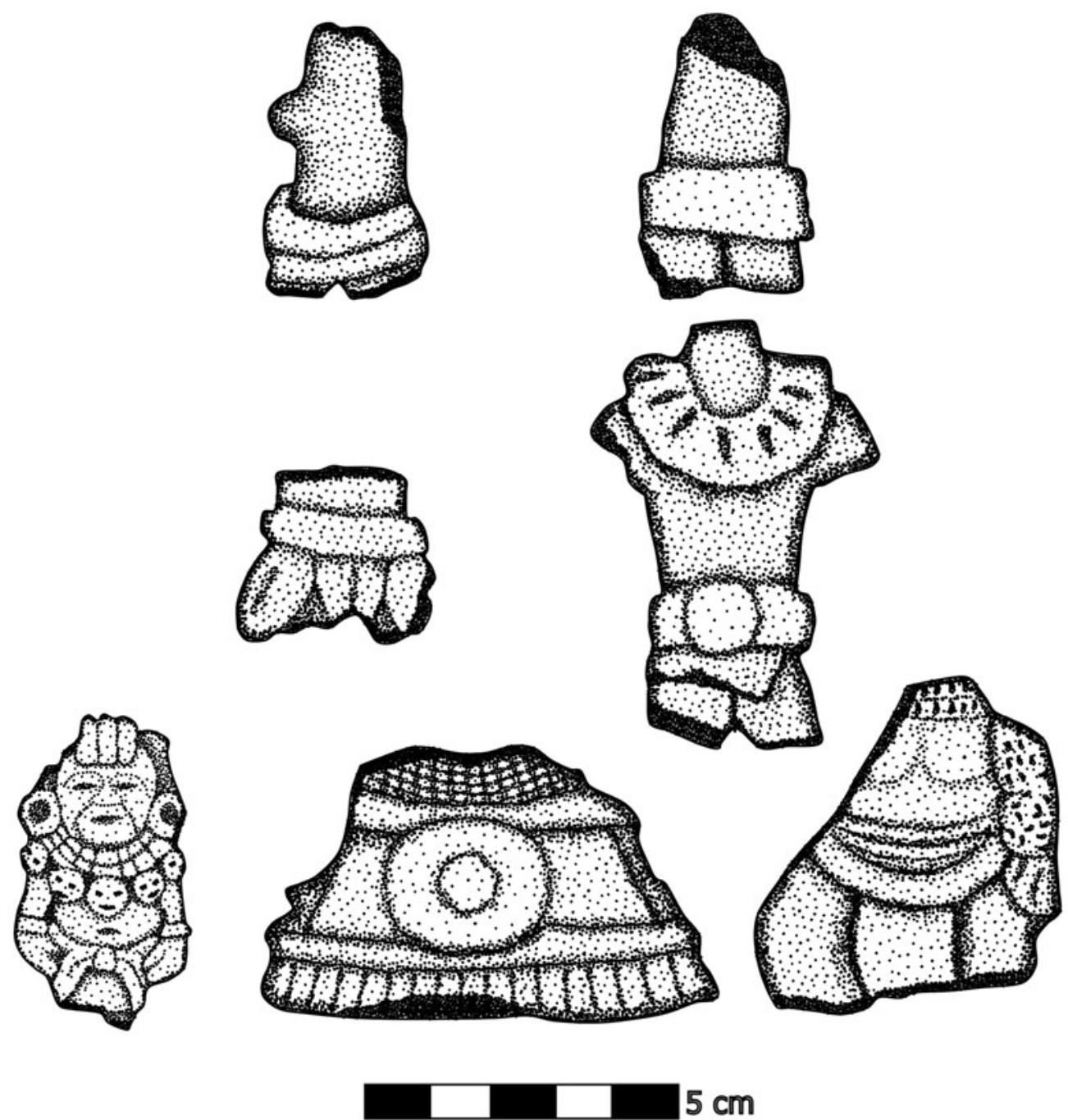

Figure 7. Teotihuacan period masculine figurines. Top: Terminal Formative figurines from Axotlan (left) and Cerro Portezuelo (right); middle: Early Classic figurines from Teotihuacan; bottom: Classic figurines from Teotihuacan (left, centre) and Axotlan (right). (Drawings: K. Hagerman.)

articulated figurines wore large amounts of jewellery). Articulated and warrior figurines formed most of the Classic period Teotihuacan assemblage, although they were somewhat less common in the rural sites, and never wore clothing, or had any features that could be interpreted as sexual attributes. Apart from these two types, though, Classic figurines invariably wore clothing, and clothed figurines outnumbered those without clothing in the rural sites, where articulated and warrior figurines were less common.

Masculine figurines diversified into multiple types during the Classic, and mould technology facilitated elaborate designs and ornamentation in clothing and jewellery. Each figurine type had its own rep- resentational rules and outfits, but there was variation within them. Half-conical figurines, for example, typically wore a long tunic, cape and jewellery (Fig. 7, bottom row centre), and some versions were rendered in rather simple detail, while others had added tassels, belts, or feathered tunics, and different combinations of jewellery. Masculine garments increased in number, diversified in style, and appeared on a number of distinct figurine types, including, but not limited to, many of the well-defined types. In this way, masculine garments seem to have been signalling not masculinity itself, but a wider range of social categories, where gender was only a facet of a more complex social identity. Classic types were stylistically and 
Table 5. Counts and rates of sexual attributes and clothing on figurines by site and period ( $A X T=$ Axotlan; $C P Z=$ Cerro Portezuelo; $H X T=$ Huixtoco; $T E O=$

Teotihuacan).

\begin{tabular}{|c|c|c|c|c|c|c|}
\hline Period & Site & $\begin{array}{c}\text { Sexual } \\
\text { attributes }\end{array}$ & Clothing & $\begin{array}{l}\text { Clothing } \\
\text { and } \\
\text { sexual } \\
\text { attributes }\end{array}$ & $\begin{array}{c}\text { None/ } \\
\text { unknown }\end{array}$ & $\begin{array}{c}\text { Total } \\
\text { torsos }\end{array}$ \\
\hline \multirow{6}{*}{$\begin{array}{l}\text { Middle } \\
\text { Formative }\end{array}$} & AXT & 2 & & & 16 & 18 \\
\hline & $\mathrm{CPZ}$ & 1 & & & 1 & 2 \\
\hline & HXT & 15 & 2 & 3 & 9 & 29 \\
\hline & TEO & & & & & \\
\hline & Total & 18 & 2 & 3 & 26 & 49 \\
\hline & $\%$ & $37 \%$ & $4 \%$ & $6 \%$ & $53 \%$ & $100 \%$ \\
\hline \multirow{6}{*}{$\begin{array}{l}\text { Late } \\
\text { Formative }\end{array}$} & AXT & 7 & 1 & 2 & 11 & 21 \\
\hline & $\mathrm{CPZ}$ & 1 & & & 1 & 2 \\
\hline & HXT & 42 & 1 & 5 & 31 & 79 \\
\hline & TEO & 1 & & 1 & 1 & 3 \\
\hline & Total & 51 & 2 & 8 & 44 & 105 \\
\hline & $\%$ & $49 \%$ & $2 \%$ & $8 \%$ & $42 \%$ & $100 \%$ \\
\hline \multirow{6}{*}{$\begin{array}{l}\text { Terminal } \\
\text { Formative }\end{array}$} & AXT & 1 & 9 & & 13 & 23 \\
\hline & $\mathrm{CPZ}$ & 7 & 7 & 1 & 18 & 33 \\
\hline & HXT & & & & & 0 \\
\hline & TEO & 45 & 218 & 6 & 518 & 787 \\
\hline & Total & 53 & 234 & 7 & 549 & 843 \\
\hline & $\%$ & $6 \%$ & $28 \%$ & $1 \%$ & $65 \%$ & $100 \%$ \\
\hline \multirow{6}{*}{$\begin{array}{l}\text { Early } \\
\text { Classic }\end{array}$} & AXT & & 27 & & 14 & 41 \\
\hline & $\mathrm{CPZ}$ & & 7 & & 6 & 13 \\
\hline & HXT & & & & & 0 \\
\hline & TEO & & 170 & & 196 & 366 \\
\hline & Total & & 204 & & 216 & 420 \\
\hline & $\%$ & & $49 \%$ & & $51 \%$ & $100 \%$ \\
\hline \multirow{6}{*}{ Classic } & AXT & & 42 & & 14 & 56 \\
\hline & $\mathrm{CPZ}$ & & 8 & & 2 & 10 \\
\hline & HXT & & 2 & & 1 & 3 \\
\hline & TEO & & 129 & & 430 & 559 \\
\hline & Total & & 181 & & 447 & 628 \\
\hline & $\%$ & & $29 \%$ & & $71 \%$ & $100 \%$ \\
\hline
\end{tabular}

formally divergent enough, however, that it is difficult to compare across them, since each type adhered to unique representational criteria.

Figurines wearing feminine clothing did not differentiate into distinct types during the Classic. Furthermore, stylistic elaboration on their clothing was minimal; sometimes a cape was added, but the combination of a simple huipil and quechquemitl were requisites that were rarely elaborated on (Figs. 6, 9). The motif of a woman holding a child was virtually the only commonality between Formative and Classic period representations of women (Fig. 9). Even though sexual attributes were replaced by cultural ones when constructing the Classic figurine body, the image of a woman and child was a recurring feature, and interestingly, the child invariably appeared on the lefthand side of the woman's body.

\section{Changing ratios of women and men over time}

In addition to waning sexual attributes and increasing clothing, there were also fluctuations in the rates of representations of men and women over time. If we consider both female sexual characteristics and 


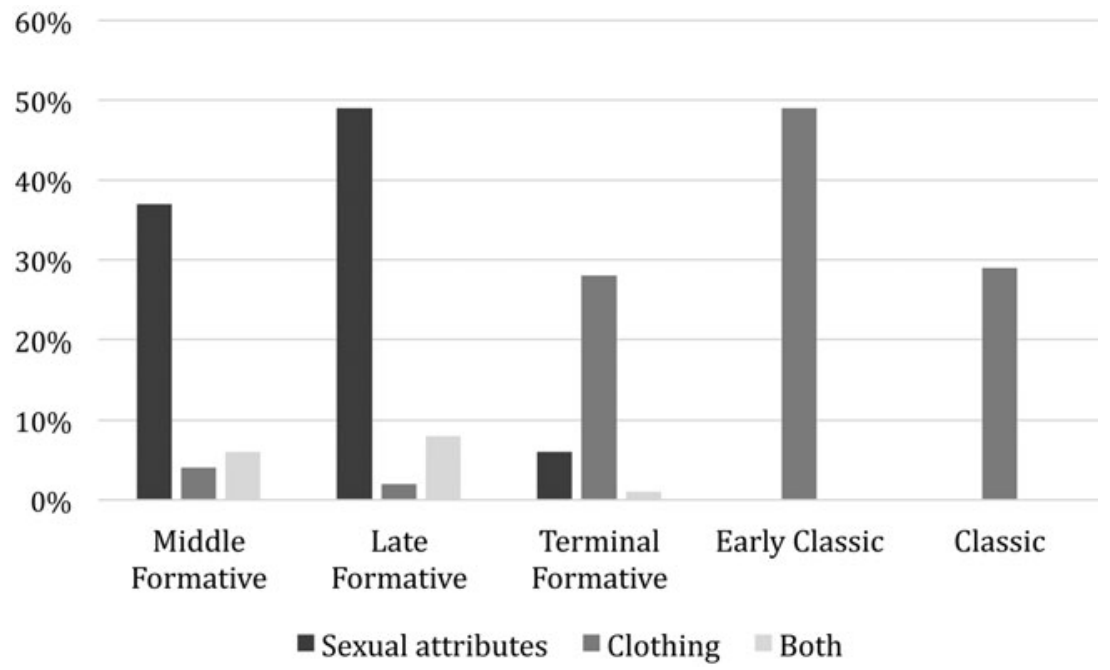

Figure 8. Rates of sexual attributes and clothing on figurines over time (all sites).
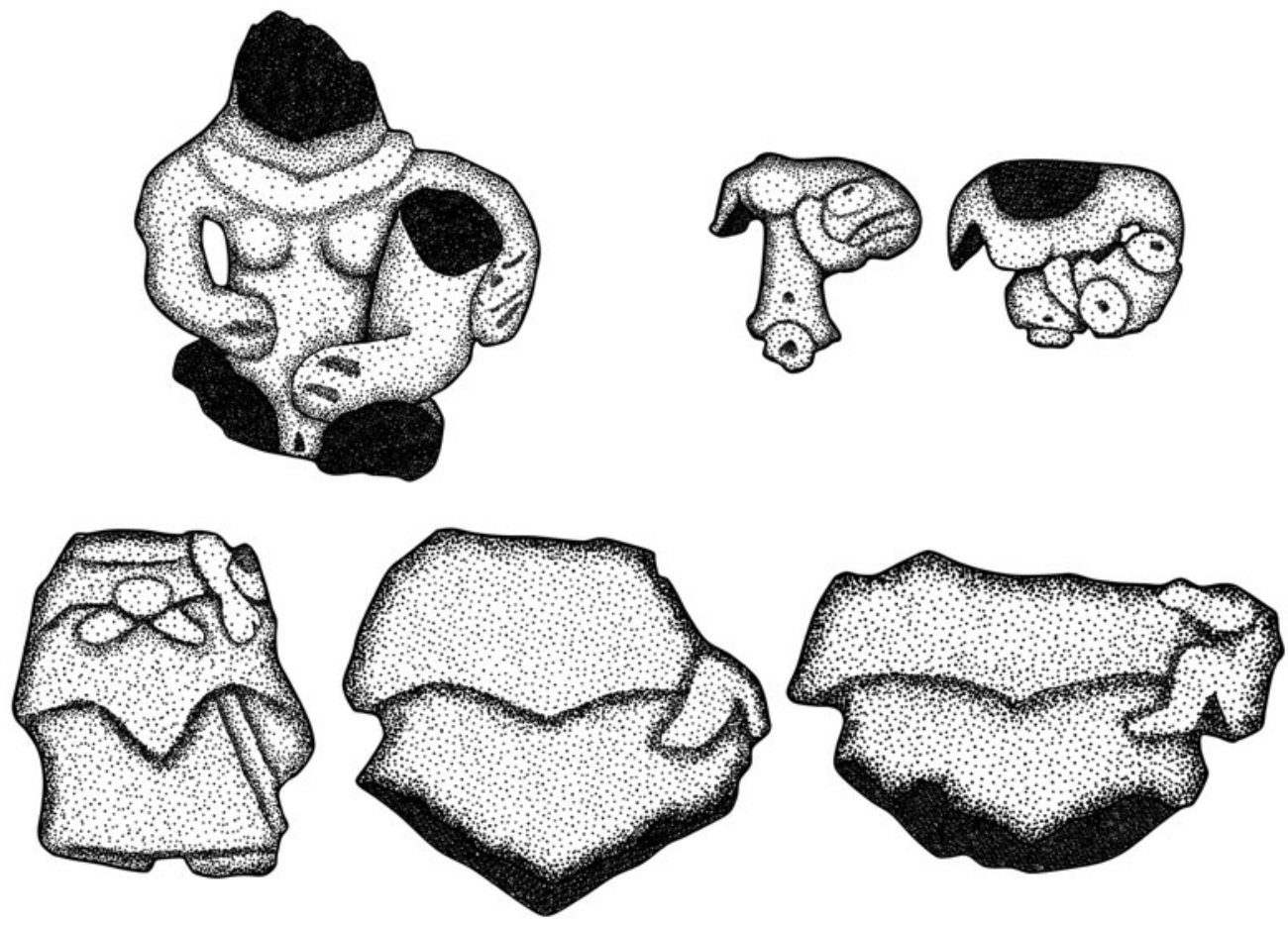

$5 \mathrm{~cm}$

Figure 9. Top row: Formative figurines from Huixtoco holding and nursing a child: bottom row: Classic figurines in huipil and quechquemitl holding children, from Teotihuacan (left, centre) and Axotlan (right). (Drawings: K. Hagerman.)

garments traditionally associated with women as strategies for depicting women, and male sexual attributes and traditional masculine garments as strategies for depicting men, then it is possible to track the respective frequencies of representations of men and women in figurine assemblages over time, the ways in which these representations changed and the de- vices used to communicate aspects of social identity and gender (Table 6). This informs us about gradual shifts in gender ideology and the changing focus of ritual practice.

Middle and Late Formative assemblages were heavily skewed towards representations of women, relying almost exclusively on biological sexual 
Transformations in Representations of Gender During the Emergence of the Teotihuacan State

Table 6. Counts and rates of sexual attributes and gendered clothing on figurines by site and period ( $A X T=$ Axotlan; $C P Z=$ Cerro Portezuelo; HXT = Huixtoco; $T E O=$ Teotihuacan).

\begin{tabular}{|c|c|c|c|c|c|c|c|c|}
\hline Period & Site & $\begin{array}{c}\text { Female } \\
\text { sexual } \\
\text { attributes }\end{array}$ & $\begin{array}{l}\text { Feminine } \\
\text { clothing }\end{array}$ & $\begin{array}{c}\text { Female } \\
\text { attributes } \\
\text { and } \\
\text { clothing }\end{array}$ & $\begin{array}{c}\text { Male } \\
\text { sexual } \\
\text { attributes }\end{array}$ & $\begin{array}{l}\text { Masculine } \\
\text { clothing }\end{array}$ & $\begin{array}{c}\text { None/ } \\
\text { unknown }\end{array}$ & $\begin{array}{l}\text { Total } \\
\text { torsos }\end{array}$ \\
\hline \multirow{6}{*}{$\begin{array}{l}\text { Middle } \\
\text { Formative }\end{array}$} & AXT & 1 & & & 1 & & 16 & 18 \\
\hline & $\mathrm{CPZ}$ & 1 & & & & & 1 & 2 \\
\hline & HXT & 15 & & 3 & & 2 & 9 & 29 \\
\hline & TEO & & & & & & & \\
\hline & Total & 17 & & 3 & 1 & 2 & 26 & 49 \\
\hline & $\%$ & $35 \%$ & & $6 \%$ & $2 \%$ & $4 \%$ & $53 \%$ & $100 \%$ \\
\hline \multirow{6}{*}{$\begin{array}{l}\text { Late } \\
\text { Formative }\end{array}$} & AXT & 7 & & 2 & & 1 & 11 & 21 \\
\hline & $\mathrm{CPZ}$ & 1 & & & & & 1 & 2 \\
\hline & HXT & 37 & & 5 & 4 & 2 & 31 & 79 \\
\hline & TEO & 1 & & 1 & & & 1 & 3 \\
\hline & Total & 46 & & 8 & 4 & 3 & 44 & 105 \\
\hline & $\%$ & $44 \%$ & & $8 \%$ & $4 \%$ & $3 \%$ & $42 \%$ & $100 \%$ \\
\hline \multirow{6}{*}{$\begin{array}{l}\text { Terminal } \\
\text { Formative }\end{array}$} & AXT & 1 & & & & 9 & 13 & 23 \\
\hline & $\mathrm{CPZ}$ & 7 & 1 & 1 & & 6 & 18 & 33 \\
\hline & HXT & & & & & & & \\
\hline & TEO & 45 & 10 & 6 & & 208 & 518 & 787 \\
\hline & Total & 53 & 11 & 7 & & 223 & 549 & 843 \\
\hline & $\%$ & $6 \%$ & $2 \%$ & $1 \%$ & & $27 \%$ & $65 \%$ & $100 \%$ \\
\hline \multirow{6}{*}{$\begin{array}{l}\text { Early } \\
\text { Classic }\end{array}$} & AXT & & 23 & & & 4 & 14 & 41 \\
\hline & $\mathrm{CPZ}$ & & 6 & & & 1 & 6 & 13 \\
\hline & HXT & & & & & & & \\
\hline & TEO & & 119 & & & 51 & 196 & 366 \\
\hline & Total & & 148 & & & 56 & 216 & 420 \\
\hline & $\%$ & & $35 \%$ & & & $13 \%$ & $51 \%$ & $100 \%$ \\
\hline \multirow{6}{*}{ Classic } & AXT & & 6 & & & 36 & 14 & 56 \\
\hline & $\mathrm{CPZ}$ & & 2 & & & 6 & 2 & 10 \\
\hline & HXT & & 1 & & & 1 & 1 & 3 \\
\hline & TEO & & 20 & & & 109 & 430 & 559 \\
\hline & Total & & 29 & & & 152 & 447 & 628 \\
\hline & $\%$ & & $5 \%$ & & & $24 \%$ & $71 \%$ & $100 \%$ \\
\hline
\end{tabular}

attributes to convey feminine identity (Table 7; Fig. 10). Representations of women accounted for 41 per cent of the assemblages in the Middle Formative and half during the Late Formative. In contrast, representations of men made up only 6 per cent of the figurines during the Middle Formative, and 7 per cent during the Late Formative. About half of Middle and Late Formative figurines did not have sexual attributes or clothing, however, and so while representations of women were common, so too were figurines where gender and sex were not made explicit through either physical features or ornamentation. Rather than interpreting these fig- urines as lacking identifiable attributes, we must be careful to consider them as deliberate and purposeful representations-representations of female bodies were common in these periods, but so were torsos that lacked these features, and their relative rates remained rather stable over a long period of time.

A shift occurred in the Terminal Formative when representations of men rose to triple the rate of women, and figurines with unknown gender accounted for two-thirds of the assemblage. This pattern was repeated during the Classic period, indicating that Teotihuacano preferences for figurines were significantly different from Formative tastes. 
Table 7. Counts and rates of gendered figurine torsos by site and period ( $A X T=$ Axotlan; $C P Z=$ Cerro Portezuelo; $H X T=$ Huixtoco; $T E O=$ Teotihuacan $)$.

\begin{tabular}{|c|c|c|c|c|c|}
\hline Period & Site & Feminine & Masculine & Unknown & Total \\
\hline \multirow{6}{*}{$\begin{array}{l}\text { Middle } \\
\text { Formative }\end{array}$} & AXT & 1 & 1 & 16 & 18 \\
\hline & $\mathrm{CPZ}$ & 1 & 0 & 1 & 2 \\
\hline & HXT & 18 & 2 & 9 & 29 \\
\hline & TEO & & & & \\
\hline & Total & 20 & 3 & 26 & 49 \\
\hline & $\%$ & $41 \%$ & $6 \%$ & $53 \%$ & $100 \%$ \\
\hline \multirow{6}{*}{$\begin{array}{l}\text { Late } \\
\text { Formative }\end{array}$} & $\mathrm{AXT}$ & 9 & 1 & 11 & 21 \\
\hline & $\mathrm{CPZ}$ & 1 & & 1 & 2 \\
\hline & HXT & 42 & 6 & 31 & 79 \\
\hline & TEO & 2 & & 1 & 3 \\
\hline & Total & 54 & 7 & 44 & 105 \\
\hline & $\%$ & $51 \%$ & $7 \%$ & $42 \%$ & $100 \%$ \\
\hline \multirow{6}{*}{$\begin{array}{l}\text { Terminal } \\
\text { Formative }\end{array}$} & $\mathrm{AXT}$ & 1 & 9 & 13 & 23 \\
\hline & $\mathrm{CPZ}$ & 9 & 6 & 18 & 33 \\
\hline & HXT & & & & \\
\hline & TEO & 61 & 208 & 518 & 787 \\
\hline & Total & 71 & 223 & 549 & 843 \\
\hline & $\%$ & $8 \%$ & $26 \%$ & $65 \%$ & $100 \%$ \\
\hline \multirow{6}{*}{$\begin{array}{l}\text { Early } \\
\text { Classic }\end{array}$} & AXT & 23 & 4 & 14 & 41 \\
\hline & $\mathrm{CPZ}$ & 6 & 1 & 6 & 13 \\
\hline & HXT & & & & \\
\hline & TEO & 119 & 51 & 196 & 366 \\
\hline & Total & 148 & 56 & 216 & 420 \\
\hline & $\%$ & $35 \%$ & $13 \%$ & $51 \%$ & $100 \%$ \\
\hline \multirow{6}{*}{ Classic } & AXT & 6 & 36 & 14 & 56 \\
\hline & $\mathrm{CPZ}$ & 2 & 6 & 2 & 10 \\
\hline & HXT & 1 & 1 & 1 & 3 \\
\hline & TEO & 20 & 109 & 430 & 559 \\
\hline & Total & 29 & 152 & 447 & 628 \\
\hline & $\%$ & $5 \%$ & $24 \%$ & $71 \%$ & $100 \%$ \\
\hline
\end{tabular}

In the Early Classic period, representations of women briefly (and for the last time) outnumbered those of men, but the majority of figurines still had undetermined gender. The poor state of preservation is potentially responsible for the low numbers of masculine figurines; since masculine attire was frequently appliquéd and confined to the waist, less of it may have survived than feminine clothing, which covered the entire body. It is also possible that clothing was not as important in marking masculine figures as it was for feminine figures, and that a figurine lacking clothing would have been interpreted as masculine. Equally possible is that a lack of clothing articulated a more salient function or social identity, and that gen- der was either not an important component of that identity, or that it was signalled in other ways that would have been recognizable to Teotihuacanos. Finally, the Terminal Formative and Early Classic may together be interpreted as a time when the criteria used to construct and communicate ideas about social identity may have been in flux, and the very ideas themselves were likely being actively negotiated as Teotihuacan grew and began to project its power into the Basin of Mexico.

In the Classic period, representations of men outnumbered those of women by five to one. At Teotihuacan, images of women were a small minority among the diffuse types of Classic figurines and made up less than 4 per cent of the Classic period assemblage. Women were noticeably more common in the three rural sites; however, the majority of the Classic period regional assemblage did not focus on women or women's bodies as an important theme.

\section{Discussion}

Gendered images in the Formative periods did not adhere to a singular manner of depiction within or between communities. Gender in Formative figurine bodies was not a simple binary invariably tied to the same anatomical markings; neither was gender in the Basin of Mexico at any point during the present study. It is true that certain sexual attributes seem to have been important features in marking gender(s), but an assemblage of features might be arranged on a single figurine body, and if we consider the figurine assemblage at the level of the community or region, then there is no fixed pattern of the selection of sexual attributes, nor their combination with other features such as jewellery or clothing.

From the Middle through Terminal Formative periods, nude bodies made up the overwhelming majority of the regional figurine assemblages. Sexual attributes were frequently included on Formative torsos and the different permutations of sexual features varied by figurine within and between site assemblages. With respect to gynomorphic Formative figurines, it does not appear that there was a common or static form being made within or between sites; the variability in spatial and diachronic distribution of sexual attributes points to subtle differences in regional figurine traditions across the Basin of Mexico in the Middle and Late Formative periods.

In addition to the figurines that contained male or female attributes, there were just as many figurines that did not contain any such features. I argue that there were likely multiple features associated with gender on figurines from the Basin of Mexico, and 


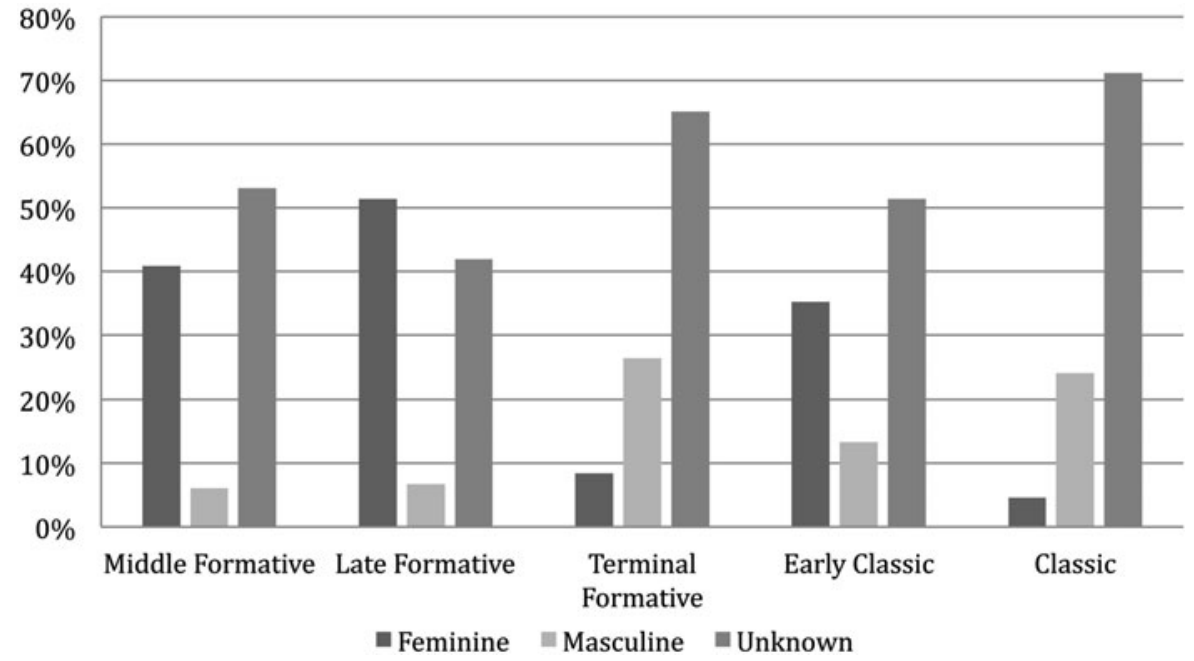

Figure 10. Rates of gendered figurines by period (all sites).

even when sexual attributes were employed in the Formative, figurines cannot be arranged in a simple dichotomous pattern using them, or any other feature. Figurine bodies seemingly were not formed with a narrow range of categories in mind, and as figurines were produced, used, traded and discarded across the Basin of Mexico, they were an active part in the formation and communication of embodied social identities, which were likely diverse and transcended a binary construction of gender. The ways in which gender factored into the bricolage of social identity, however, may have been significantly different between the Formative and Classic periods.

When Teotihuacan-style figurines began to appear regionally in the Terminal Formative, they were fundamentally different in several key ways. Teotihuacan figurines never went through a period where sexual attributes were exceedingly common or diverse, suggesting disinterest with this form of visual representation. The transition to fully clothed representations of women was a further departure from Formative figurine traditions. Culturally relevant ornaments and costumes that adorned the body became more relevant signs of gendered social identities than biological features on nude bodies. The Teotihuacan figurine tradition likely did not include such physical features because they were not determinants of how social difference was generated and ascribed, or because the uses of the figurines did not necessitate the depiction of such features. The increasing importance of ostentatious clothing and jewellery on figurines during the Teotihuacan period signals a concern for social position, wealth and, perhaps, occupation, which is not surprising in a rapidly stratifying society.
As we examine changes in visual imagery and their relationship to gender in society, the respective 'visibility' of women and men is important to consider. As Teotihuacan society became increasingly stratified, feminine figurines became increasingly standardized and rare. The numerous female figurines in the Formative periods had been spaces of variation and difference, whereas in Classic Teotihuacan society the feminine body was fixed and extremely limited in terms of allowable variation. Masculine bodies were now the spaces for diversity, elaboration and experimentation, and feminine bodies were rendered in a different visual language, which prioritized simplicity over the ostentation of contemporary masculine figures. The resulting visual effect, which both mediated and reflected human construction and perception of the social world, was one of gendered difference. That is not to claim that women were second-class citizens in the new order; in fact, one of the most puzzling aspects of Teotihuacan representational art is the apparent lack of images of rulers, and one would not argue that no one wielded political authority in Teotihuacan society. Women may have been important participants in ritual at the household, compound, or district level-there is insufficient evidence to conclude one way or another-but the subject matter of the Classic period figurines indicates a qualitative difference from Formative assemblages that likely extends to the ways figurines were used and perhaps even how women featured in domestic ritual practice.

We might speak of the efficacy of certain attributes including, but not limited to, sexual attributes in the Formative, and the efficacy of clothing and jewellery in the Classic, as these were choices that were 
often repeated within local and regional figurine assemblages. The selection (or absence as a form of selection) and combination of such traits, however, does not follow readily discernable patterns that are easily divided into a limited number of groups. Throughout the Formative periods, a large portion of the assemblages were made up by figurines with no sexual attributes at all, and importantly, this element persisted in the Teotihuacan style. As the ratios of masculine and feminine figurines changed and the visual language used to express such ideas shifted, a large proportion of the regional assemblages continued to be made up of figurines that did not clearly fall into simple masculine/feminine dichotomies based on physical attributes or ornamentation, and attempts to arrange them this way likely says more about the people doing the sorting than it does about the people who produced them.

We may never know precisely what social identities were being represented in Formative and Classic figurine assemblages, but the diversity of images across all periods indicates that more was being represented than essentialized depictions of masculinity and femininity alone. Nevertheless, the rules of representation for aspects of social identity underwent dramatic changes at the start of the Teotihuacan period, some of which strongly point to a revision of gender ideologies in the region. The replacement of nude bodies with clothed and heavily ornamented ones and the proliferation of specific and distinct figurine types indicates a dramatic change in a component of domestic ritual practice both within the city and in its rural hinterland.

\section{Conclusion}

As the Teotihuacan state developed into a regional power and Basin society became increasingly hierarchical, interest in representing the physical body modified to an emphasis on the socially constructed person. The changes in the Basin of Mexico figurine assemblages related to depictions of humans is evidence of a general societal transformation that occurred alongside the emergence of the Teotihuacan state, which had profound effects on the gender ideologies of regional communities. But, importantly, at no point do the figurines indicate that gender systems in the Basin of Mexico were simple, dichotomous affairs. No period or site contained figurines that could be easily reduced to just 'men' and 'women', and the more complex renderings of human bodies at the individual and regional levels of assemblage reveal an interest in complex, variable and dynamic social identities, which changed over time.
Figurines are only one element of a complex material culture, and attempting to reconstruct gender over the course of a millennium using one class of objects may seem akin to trying to complete a jigsaw puzzle with only a handful of pieces right side up. But my goal in discussing these objects in such a way is that they are an integral, undeniable source of evidence on how human bodies were perceived and valued, and how the myriad facets of social and gendered identity were constructed, maintained, or changed across space and over long periods of time. Although they are in themselves insufficient for unravelling the complexities of gender in ancient Basin of Mexico society, so too are they indispensable in this pursuit.

Kiri Hagerman
San Jose, CA
USA
Email:khagerman@ucsd.edu

\section{References}

Bachand, H., R.A. Joyce \& J.A. Hendon, 2003. Bodies moving in space: ancient Mesoamerican human sculpture and embodiment. Cambridge Archaeological Journal 13, 238-47.

Bahrani, Z., 2001. Women of Babylon: Gender and representation in Mesopotamia. New York (NY): Routledge.

Barbour, W., 1975. The Figurines and Figurine Chronology of Ancient Teotihuacan Mexico. PhD dissertation, University of Rochester (USA).

Brumfiel, E.M., 1996. Figurines and the Aztec state: testing the effectiveness of ideological domination, in Gender and Archaeology, ed. R.P. Wright. Philadelphia (PA): University of Pennsylvania, 143-66.

Brumfiel, E.M., 2001. Aztec hearts and minds: religion and the state in the Aztec empire, in Empires: Perspectives from archaeology and history, eds. S.E. Alcock, T. D'Altroy, K.D. Morrison \& C.M. Sinopoli. Cambridge: Cambridge University Press, 283-310.

Brumfiel, E.M., 2007. Methods in feminist and gender archaeology: a feeling for difference - and likeness, in Women in Antiquity: Theoretical approaches to gender and archaeology, ed. S.M. Nelson. Lanham (MD): AltaMira, 1-28.

Butler, J., 1993. Bodies That Matter: On the discursive limits of sex. New York (NY): Routledge.

Butler, J., 1999. Gender Trouble: Feminism and the subversion of identity. New York (NY): Routledge.

Cabrera Castro, R., I. Rodriguez Garcia \& N. Morelos Garcia (eds.), 1991. Teotihuacan 1980-1982: Nuevas Interpretaciones. Mexico City: Instituto Nacional de Antropologia e Historia.

Cabrera Cortés, M.O., 2011. Craft Production and SocioEconomic Marginality: Living on the Periphery of Urban 
Teotihuacan. PhD dissertation, Arizona State University.

Carballo, D.M., 2007. Effigy vessels, religious integration, and the origins of the central Mexican pantheon. Ancient Mesoamerica 18(1), 53-67.

Clayton, S.C., 2009. Ritual Diversity and Social Identities: A Study of Mortuary Behaviors at Teotihuacan. PhD dissertation, Arizona State University.

Clayton, S.C., 2011. Gender and mortuary ritual at ancient Teotihuacan, Mexico: a study of intrasocietal diversity. Cambridge Archaeological Journal 21(1), 31-52.

Clayton, S.C., 2013. Measuring the long arm of the state: Teotihuacan's relations in the Basin of Mexico. Ancient Mesoamerica 24(1), 87-105.

Conkey, M.W. \& J.M. Gero, 1991. Tensions, pluralities, and engendering archaeology: an introduction to women and prehistory, in Engendering Archaeology: Women and prehistory, eds. J.M. Gero \& M.W. Conkey. Oxford: Blackwell, 3-30.

Conkey, M.W. \& C. Hastorf (eds.), 1990. The Uses of Style in Archaeology. New York (NY): Cambridge University Press.

Cowgill, G.L., 1997. State and society at Teotihuacan, Mexico. Annual Review of Anthropology 26(1), 129-61.

Cowgill, G.L., 2015. Ancient Teotihuacan: Early urbanism in Central Mexico. New York (NY): Cambridge University Press.

Crellin, R.J., 2017. Changing assemblages: vibrant matter in burial assemblages. Cambridge Archaeological Journal 27(1), 111-25.

De Lucia, K., 2008. Looking beyond gender hierarchy: rethinking gender at Teotihuacan, Mexico. Archaeological Papers of the American Anthropological Association 18(1), 17-36.

DeLanda, M., 2006. A New Philosophy of Society: Assemblage theory and social complexity. London: Continuum.

Deleuze, G. \& F. Guattari, 1987. A Thousand Plateaus. London: Continuum.

Faust, K.A. \& C.T. Halperin, 2009. Approaching Mesoamerican figurines, in Mesoamerican Figurines: Small-scale indices of large-scale social phenomena, eds. C.T. Halperin, K.A. Faust, R. Taube \& A. Giguet. Gainsville (FL): University Press of Florida, 1-22.

Fisher, G. \& D.D. Loren, 2003. Embodying identity in archaeology. Cambridge Archaeological Journal 13(2), 22530.

Fowler, C., 2017. Relational typologies, assemblage theory and early bronze age burials. Cambridge Archaeological Journal 27(1), 95-109.

Gailey, C.W., 1985. The state of the state in anthropology. Dialectical Anthropology 9, 65-89.

Gamboa Cabezas, L.M. \& M. García Sánchez, 2015. Prácticas mortuorias de un asentamiento rural Prehispánico en San Marcos Huixtoco, Ixtapaluca, Estado de México [Mortuary practices from a Prehispanic rural settlement in San Marcos Huixtoco, Ixtapaluca, State of Mexico]. Vita Brevis 4(7), 1-22.
García Chávez, R., L.M. Gamboa Cabezas \& N. Vélez Saldaña, 2004. Informe Final de Las Actividades Realizadas En El Predio de San Ignacio Y La Loma, Del Poblado de Axotlan, Municipio de Cuautitlan Izcalli, Estado de México [Final report of the activities performed at the site of San Ignacio and La Loma, from the town of Axotlan, Municipality of Cuautitlan Izcalli, State of Mexico]. Mexico City: Instituto Nacional de Antropologia e Historia.

García Chávez, R.E., L.M. Gamboa Cabezas \& N.V. Saldaña, 2015. Los sitios rurales y la estrategia expansionista del estado Teotihuacano para la captacion de recursos en La Cuenca de México[The rural sites and the expansionary strategy of the Teotihuacan state to acquire resources in the Basin of Mexico]. Ancient Mesoamerica 26(2), 423-42.

Gell, A., 1998. Art and Agency: An anthropological theory. Oxford: Oxford University Press.

Geller, P.L., 2009a. Identity and difference: complicating gender in archaeology. Annual Review of Anthropology 38(1), 65-81.

Geller, P.L., 2009b. Bodyscapes, biology, and heteronormativity. American Anthropologist 111(4), 504-16.

German, S.C., 2000. The human form in the Late Bronze age Aegean, in Reading the Body: Representations and remains in the archaeological record, ed. A.E. Rautman. Philadelphia (PA): University of Pennsylvania Press, 95-110.

Gero, J.M. \& M.C. Scattolin, 2002. Beyond complementarity and hierarchy: new definitions for archaeological gender relations, in In Pursuit of Gender: Worldwide archaeological approaches, eds. S.M. Nelson \& R.-A. Myriam. Walnut Creek (CA): AltaMira, 155-72.

Goldsmith, K.C., 2000. Forgotten Images: A Study of the Ceramic Figurines From Teotihuacan, Mexico. PhD dissertation, University of California Riverside.

Graff, S.B., 2014. Sexuality, reproduction and gender in terracotta plaques from the Late Third-Early Second millennia BCE, in Critical Approaches to Ancient Near Eastern Art, eds. B.A. Brown \& M.H. Feldman. Berlin: De Gruyter, 371-90.

Hagerman, K., 2018. Domestic Ritual and Identity in the Teotihuacan State: Exploring Regional Processes of Social Integration Through Ceramic Figurines. PhD dissertation, University of California San Diego.

Hamilakis, Y., 2017. Sensorial assemblages: affect, memory and temporality in assemblage thinking. Cambridge Archaeological Journal 27(1), 169-82.

Hamilakis, Y. \& A.M. Jones, 2017. Archaeology and assemblage. Cambridge Archaeological Journal 27(1), 77-84.

Hegmon, M., 1992. Archaeological research on style. Annual Review of Anthropology 21, 517-36.

Hicks, F., 2013. The architectural features of Cerro Portezuelo. Ancient Mesoamerica 24(1), 73-85.

Hodder, I., 1990. Style as historical quality, in The Uses of Style in Archaeology, eds. M.W. Conkey \& C. Hastorf. New York (NY): Cambridge University Press, $44-51$. 
Hollimon, S.E., 2000. Archaeology of the 'Aqi: gender and sexuality in prehistoric Chumash society, in Archaeologies of Sexuality, eds. R.A. Schmidt \& B.L. Voss. London: Routledge, 179-96.

Insoll, T., 2007. Introduction: configuring identities in archaeology, in The Archaeology of Identities: A reader, ed. T. Insoll. New York (NY): Routledge, 1-18.

Jones, A.M., 2017. The art of assemblage: styling Neolithic art. Cambridge Archaeological Journal 27(1), 85-94.

Joyce, R.A., 2000. Girling the girl and boying the boy: the production of aduthood in ancient Mesoamerica. World Archaeology 31(3), 473-83.

Joyce, R.A., 2003. Make something of herself: embodiment in life and death at Playa de los Muertos, Honduras. Cambridge Archaeological Journal 13(2), 248-61.

Joyce, R.A., 2004. Embodied subjectivity: gender, femininity, masculinity, sexuality, in A Companion to Social Archaeology, eds. L. Meskell \& R.W. Preucel. Malden (MA): Blackwell, 82-95.

Joyce, R.A., 2005. Archaeology of the body. Annual Review of Anthropology 34(1), 139-58.

Knapp, A.B. \& P. van Dommelen, 2008. Past practices: rethinking individuals and agents in archaeology. Cambridge Archaeological Journal 18(1), 15-34.

Lee, M.M., 2000. Deciphering gender in Minoan dress, in Reading the Body: Representations and remains in the archaeological record, ed. A.E. Rautman. Philadelphia (PA): University of Pennsylvania Press, 111-23.

Lee, M.M., 2015. Body, Dress, and Identity in Ancient Greece. Cambridge: Cambridge University Press.

Lesure, R.G., 2011. Interpreting Ancient Figurines: Context, comparison, and prehistoric art. New York (NY): Cambridge University Press.

Lesure, R.G., 2015. Prehistoric figurine styles as fashion: a case from Formative central Mexico. Cambridge Archaeological Journal 25(1), 99-119.

Linné, S., 1934. Archaeological Researches at Teotihuacan, Mexico. Stockholm: Ethnographical Museum of Sweden.

MacKinnon, C.A., 1982. Feminism, Marxism, method, and the state. Signs: Journal of Women in Culture and Society 7(3), 515-44.

Manzanilla, L. (ed.), 1993. Anatomía de Un Conjunto Residencial Teotihuacano En Oztoyahualco: Los Estudios Especiales. Mexico City: UNAM.

Manzanilla, L., 1996. Corporate groups and domestic activities at Teotihuacan. Latin American Antiquity 7(3), 22846.

Manzanilla, L., 2002. Living with the ancestors and offering to the gods: domestic ritual at Teotihuacan, in Domestic Ritual in Ancient Mesoamerica, ed. P. Plunket. Los Angeles (CA): Cotsen Institute of Archaeology, 43-52.

Manzanilla, L., 2004. Social identity and daily life at Classic Teotihuacan, in Mesoamerican Archaeology, eds. J.A. Hendon \& R.A. Joyce. Malden (MA): Blackwell, 124-47.

Manzanilla, L., 2012. Teopancazco, un Centro de Barrio Multiétnico de Teotihuacan, in Estudios Arqueométri- cos Del Centro de Barrio de Teopancazco En Teotihuacan ed. L. Manzanilla. Mexico City: UNAM.

Marcus, J., 2009. Rethinking figurines, in Mesoamerican Figurines: Small-scale indices of large-scale social phenomena, eds. C.T. Halperin, K.A. Faust, R. Taube \& A. Giguet. Gainsville (FL): University Press of Florida, 25-50.

Meskell, L., 1998. Intimate archaeologies: the case of Kha and Merit. World Archaeology 29(3), 363-79.

Meskell, L., 2002. The intersections of identity and politics in archaeology. Annual Review of Anthropology 31, 279301.

Millon, R., 1973. Urbanization at Teotihuacán, Mexico, Vol. 1. The Teotihuacán Map, Part 1: Text. Austin (TX): University of Texas Press.

Montoya, J., 2001. Terracotta figurines from the Pyramid of the Moon at Teotihuacan, Mexico. (FAMSI Report 2001.) http://www.famsi.org/reports/98060/index.html

Moral, E., 2016. Qu(e)erying sex and gender in archaeology: a critique of the 'third' and other sexual categories. Journal of Archaeological Method and Theory 23(3), 788809.

Nelson, S.M., 2004. Gender in Archaeology: Analyzing power and prestige. Walnut Creek (CA): AltaMira.

Nelson, S.M. (ed.), 2006. Handbook of Gender in Archaeology. Lanham (MD): AltaMira.

Nelson, S.M. (ed.), 2007. Women in Antiquity: Theoretical approaches to gender and archaeology. Lanham (MD): AltaMira.

Nichols, D.L., 2016. Teotihuacan. Journal of Archaeological Research 24(1), 1-74.

Nichols, D.L., H. Neff \& G.L. Cowgill, 2013. Cerro Portezuelo: states and hinterlands in the pre-hispanic Basin of Mexico. Ancient Mesoamerica 24(1), 47-71.

Nicholson, H.B. \& F. Hicks, 1961. A brief progress report on the excavations at Cerro Portezuelo, Valley of Mexico. American Antiquity 27(1), 106-8.

Robb, J. \& O.J.T. Harris, 2018. Becoming gendered in European prehistory: was Neolithic gender fundamentally different? American Antiquity 83(1), 128-47.

Rodriguez Sanchez, E.A. \& J. Delgado Rubio, 1997. Una ofrenda cerámica al este de la antigua ciudad de Teotihuacan [A ceramic offering to the east of the old city of Teotihuacan]. Arqueologia 18, 17-22.

Roscoe, W., 1998. Changing Ones: Third and fourth genders in Native North America. London: Macmillan.

Sacks, K., 1976. State bias and women's status. American Anthropologist 78, 565-9.

Schmidt, R.A. \& B.L. Voss (eds.), 2000. Archaeologies of Sexuality. London: Routledge.

Scott, S., 1994. Terracotta Figurines from Ancient Teotihuacan: Typology and Iconographic Themes. PhD thesis, University College London.

Scott, S., 2001. The Corpus of Terracotta Figurines from Sigvald Linne's Excavations at Teotihuacan, Mexico (1932 E 1934-1935) and Comparative Material. Stockholm: The National Museum of Ethnography.

Sempowski, M.L., 1994. Mortuary practices at Teotihuacan, in Mortuary Practices and Skeletal Remains 
at Teotihuacan, eds. M.L. Sempowski \& M.W. Spence. Salt Lake City (UT): University of Utah Press, $1-314$.

Silverblatt, I., 1988. Women in states. Annual Review of Anthropology 17, 427-60.

Spencer-Wood, S.M., 2011. Introduction: feminist theories and archaeology. Archaeologies: Journal of the World Archaeological Congress 7(1), 1-33.

Sugiyama, N., S. Sugiyama \& S. Alejandro, 2013. Inside the Sun Pyramid at Teotihuacan, Mexico: 2008-2011 excavations and preliminary results. Latin American Antiquity 4, 403-32.

Sugiyama, S., 2002. Censer symbolism and the state polity in Teotihuacan. FAMSI report. http:/ / www.famsi.org/ reports/97050/97050Sugiyama01ImagesTeo.pdf

Sugiyama, S. \& R. Cabrera Castro, 2007. The Moon Pyramid Project and the Teotihuacan State polity: a brief summary of the 1998-2004 excavations. Ancient Mesoamerica $18,109-25$.

Sullivan, K., 2007. Commercialization in Early State Economies: Craft Production and Market Exchange in Classic Period Teotihuacan. PhD dissertation, Arizona State University.

Sweely, T.L. (ed.), 1999. Manifesting Power: Gender and the interpretation of power in archaeology. London: Routledge.

Uruñuela, G. \& P. Plunket, 2007. Tradition and transformation: village ritual at Tetimpa as a template for early Teotihuacan, in Commoner Ritual and Ideology in Ancient Mesoamerica, ed. J.C. Lohse. Boulder (CO): University Press of Colorado, 33-54.
Vaillant, G.C., 1930. Excavations at Zacatenco. New York (NY): American Museum of Natural History.

Vaillant, G.C., 1931. Excavations at Ticoman. New York (NY): American Museum of Natural History.

Vaillant, S.B. \& G.C. Vaillant, 1934. Excavations at Gualupita. New York (NY): American Museum of Natural History.

Voss, B.L., 2008. Sexuality studies in archaeology. Annual Review of Anthropology 37, 317-36.

White, C.D., M.W. Spence, F.J. Longstaffe \& K.R. Law, 2004. Demography and ethnic continuity in the Tlailotlacan enclave of Teotihuacan: the evidence from stable oxygen isotopes. Journal of Anthropological Archaeology 23, 385-403.

Wylie, A., 2007. The constitution of archaeological evidence: gender politics and science, in The Archaeology of Identities: A reader, ed. T. Insoll. New York (NY): Routledge, 97-118.

\section{Author biography}

Kiri Hagerman has a PhD in Anthropological Archaeology from the University of California San Diego. She has conducted fieldwork in Mexico, Belize and Syria and specializes in the archaeology of state-level societies in Mesoamerica with a focus on art and iconography in Teotihuacan society, and figurine traditions in the Basin of Mexico. Her general research interests include the emergence of hierarchical societies, gender, ideology and domestic ritual practices. 